Discussion Paper No. 09-044

\title{
Decreasing Wage Mobility in Germany
}

Johannes Gernandt

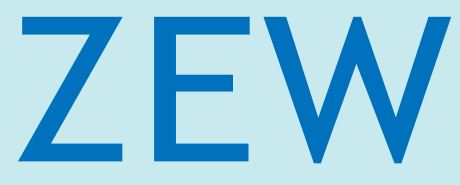

Zentrum für Europäische Wirtschaftsforschung $\mathrm{GmbH}$

Centre for European

Economic Research 
Discussion Paper No. 09-044

\title{
Decreasing Wage Mobility in Germany
}

\author{
Johannes Gernandt
}

Download this ZEW Discussion Paper from our ftp server:

ftp://ftp.zew.de/pub/zew-docs/dp/dp09044.pdf

Die Discussion Papers dienen einer möglichst schnellen Verbreitung von neueren Forschungsarbeiten des ZEW. Die Beiträge liegen in alleiniger Verantwortung der Autoren und stellen nicht notwendigerweise die Meinung des ZEW dar.

Discussion Papers are intended to make results of ZEW research promptly available to other economists in order to encourage discussion and suggestions for revisions. The authors are solely responsible for the contents which do not necessarily represent the opinion of the ZEW. 


\section{Non-technical summary}

Cross-section inequality increased in the last decade in Germany. Wage mobility can at least partly offset the increase in cross-section inequality and thus leads to a better understanding of inequality and poverty in a society. If wages are immobile, rising cross-section inequality is associated with a rising inequality of lifetime earnings. On the other hand, the extreme case of total mobility would resemble a lottery re-starting at the beginning of every time period and repositioning the individual at random in the wage distribution. The study at hand analyses the development of the wage mobility in Germany over the last 25 years.

The data base of this empirical study is the German Socio-economic Panel (SOEP) for the time period 1984 to 2007, focusing on West Germans. The SOEP is a representative panel data set, which surveys about 11,000 households with 20,000 persons. Wage mobility in terms of the paper at hand is measured by the degree to which ranks are reversed over a 4year time period where each rank represents one of 100 percentiles of the overall hourly wage distribution. The goal is to look at the individual turnover of persons within the wage distribution at the micro level to identify properties affecting wage mobility.

The main findings show that wage mobility has decreased over time, while inequality has increased. Mobility is highest in the middle section of the distribution and highest for persons aged 30-39 years. Individual upgrades in the wage distribution are more likely to occur for university graduates, younger workers, employees in larger firms and for persons working in the public sector, as well as for white-collar workers and less likely for persons who faced an unemployment period in the time of observation. Wages are more volatile in the low-wage sector and for individuals moving downwards in the wage distribution. 


\section{Das Wichtigste in Kürze}

Seit Mitte der 1990er Jahre ist die Lohnungleichheit in Deutschland im Querschnitt gestiegen. Um die gesellschaftlichen Folgen dieser Entwicklung richtig zu beurteilen, muss jedoch zusätzlich die Dimension der Lohnmobilität in den Blick genommen werden. Hohe Lohnmobilität würde bedeuten, dass Bürger im Laufe ihres Erwerbslebens gute Chancen hätten, ihre individuelle Position in der Einkommensverteilung der Bevölkerung zu verbessern. Bei niedrigerer Lohnmobilität wäre die individuelle Einkommensposition dagegen quasi zementiert. Für den Einzelnen gäbe es wenig Anreize, z.B. in Humankapital zu investieren. Ohne die Dimension der Lohnmobilität zu berücksichtigen, lassen sich Aussagen zu Armut und Ungleichheit der Gesellschaft anhand der Lohnungleichheit im Querschnitt somit nur bedingt treffen. Vor diesem Hintergrund untersucht die vorliegende Studie, wie sich die Lohnmobilität in Deutschland in den letzten 25 Jahren entwickelt hat.

Die Datenbasis dieser empirischen Studie ist das Sozio-oekonomische Panel (SOEP) für den Zeitraum 1984 bis 2007 für Westdeutschland. Das SOEP ist ein repräsentativer Längsschnittdatensatz mit zurzeit etwa 20.000 teilnehmenden Personen in 11.000 Haushalten. In der vorliegenden Arbeit wird Lohnmobilität daran gemessen, wie sich die Position einzelner Personen innerhalb von 4 Jahren in der Lohnverteilung verändert. Die Verteilung der Bruttostundenlöhne wird dazu jedes Jahr in 100 Perzentile aufgeteilt, wobei jedes Perzentil einen Lohnrang repräsentiert. Das Ziel der Untersuchung ist es, zu quantifizieren wie sich sozioökonomische Erklärungsgrößen auf die Lohnmobilität einzelner Individuen auswirken.

Die wichtigsten Ergebnisse zeigen, dass sich die Lohnmobilität im Laufe des Untersuchungszeitraums verringert hat, während die Lohnungleichheit gestiegen ist. Die Lohnmobilität ist am höchsten im mittleren Bereich der Verteilung und für Personen im Alter von 30 bis 39 Jahren. Aufstiege in höhere Lohnränge sind wahrscheinlicher für Hochschulabsolventen, Arbeitnehmer in größeren Unternehmen und für Personen im öffentlichen Sektor, sowie für Angestellte und weniger wahrscheinlich für Personen, die eine Arbeitslosigkeitsperiode im Untersuchungszeitraum aufweisen. Die Löhne sind volatiler im Niedriglohnbereich und für Personen, die in der Lohnverteilung absteigen. 


\title{
Decreasing Wage Mobility in Germany
}

\author{
Johannes Gernandt \\ ZEW Centre for European Economic Research, Mannheim
}

This version: 1st September 2009

\begin{abstract}
Using data from the German Socio Economic Panel (SOEP) for the years 1984 to 2007, this paper analyses the amount, the development and the explanations of wage mobility, as well as volatility in West Germany, measured by ranks in the wage distribution. Individual wage mobility decreased between 1984/1987 and 2004/2007, while inequality increased steadily from the mid 1990s onwards. Mobility is highest in the middle section of the distribution. Better qualified persons, younger persons and employees of larger firms have higher chances of moving upwards. Wages are more volatile in the low-wage sector and for individuals moving downwards in the wage distribution.
\end{abstract}

Keywords: Wage Mobility, Ranks, Inequality, Distribution, SOEP

JEL-classification: J31, J60, D31

\section{Corresponding author:}

Johannes Gernandt, Centre for European Economic Research, P.O. Box 103443, D-68034 Mannheim. Tel.: +49-621-1235-288, E-mail: gernandt@zew.de

\section{Acknowledgements:}

I would like to thank my colleagues from the ZEW who participated at an internal seminar for their helpful comments, especially Nicole Gürtzgen and Friedhelm Pfeiffer for several additional hints. For fine research assistance I thank Heidi Hellerich, Falco Möller, Ana Maria Montoya and Ruben Seiberlich. All remaining errors are my own. 


\section{Introduction}

Inequality is a topic of wide interest in the economic literature and in the public discussion. While wage inequality in the U.S. started to increase rapidly in the mid 1980s (see e.g. Acemoglu, 2002, 2003, Autor et al., 2008, DiNardo et al., 1996), the situation in continental Europe, especially in Germany, was characterised as more or less stable for a long time. This changed, in the mid-1990s, when wage inequality began to increase there, as well (see e.g. Dustmann et al., 2009, Gernandt and Pfeiffer, 2007, Kohn, 2006). These studies look at crosssection wage inequality and thus provide a snapshot of the inequality measured. Although they try to analyse the reasons behind the evolution of inequality over time with decomposition methods, such methods may have some shortcomings in the face of unobserved individual effects. Therefore in this paper, I try to investigate wage mobility more directly, looking at selected longitudinal samples of workers.

One shortcoming of such snapshots is that they do not encompass a wide range of an individual's options, particularly the chance to move, e.g. to leave low-wage areas. This raises the question of wage mobility. How much mobility is there? What opportunities for wage mobility did there exist in Germany during the last years? Wage mobility can at least partly offset the increase in cross-section inequality and thus leads to a better understanding of inequality and poverty in a society. If wages are immobile, rising cross-section inequality is associated with a rising inequality of lifetime earnings. On the other hand, the extreme case of total mobility would resemble a lottery re-starting at the beginning of every time period and repositioning the individual at random in the wage distribution - hence, apart from potential credit crunches, "snapshot inequality” would be no problem. Thus, mobility could lead to shared inequality among persons. In general, mobility can be regarded as positive because it reduces inequality. The downside, however, is that it leads to insecurity of further income and this potentially influences investment decisions, e.g. in education or family planning.

Several ways to measure wage mobility are practicable. One way is to calculate individual wage growth from one period to another e.g. from year to year. There is an extensive debate about wage rigidities in the sense that if wages as a whole are not flexible, downside wage rigidities are likely to occur. Cornelißen and Hübler (2008) use the SOEP from 1984 to 2004 and observe an annual nominal mean wage growth of $4.1 \%$. Without downside wage rigidity, this would be only 0.9\%. Pfeiffer (2003) uses the IABS from 1975 to 1995 and establishes individual nominal wage growth rates between $3 \%$ and $8 \%$, which decrease over the time 
period. Another line in the literature is to analyse intergenerational wage mobility, e.g. how the wage of the son is related to the wage of his father (see e.g. Solon (1992) for the U.S. and Eisenhauer and Pfeiffer (2008) for Germany). These studies report a wage elasticity from about 0.3 in Germany and about 0.4 in the U.S.

It is not only the absolute amount of the wage that seems to be of importance for the individual but also the relative wage compared to other workers, e.g. measured by ranks within the wage distribution. Summers (1988) argues, and thus reinforces Keynes (1936), that the employee's productivity is affected by the absolute wage and also by the relative wage. Add on the so-called Easterlin paradox (Easterlin, 1974, 1995) that over the last decades, the real average income in Western industrialized countries increased substantially, while on the other hand, average satisfaction or happiness remained stable; it is established that the relative income position has a significant influence for individual happiness - a higher relative wage is positively correlated with happiness (see e.g. Clark et al., 2008, Clark and Oswald, 1996, Luttmer, 2005). Using British labour data, as well as an experimental approach, Brown et al. (2008) find that the ordinal rank also has a significant effect on well-being. Thus, it is useful to look at the whole wage distribution. Besides the Easterlin paradox, Brown et al. (2008) provide two additional intuitive arguments: the first is derived from evolutionary biology, which states that females favour a mate within a hierarchy of possible sexual partners, ordered according to the possession of resources that will be available for offspring. Second, casual observations in the world of human beings show that people are interested in rankings, e.g. sport outcomes, incomes as described in newspapers, "rich lists” or even lists of economists (as in repec.org or in the German Handelsblatt ranking). In this sense, the absolute difference between the ranks is not so important for individuals - e.g. a gold medal for rank 1, nothing for rank 4 independent of the absolute output difference.

The paper at hand follows this last approach: Wage mobility is measured by the degree to which ranks are reversed over time. The goal is to look at the individual turnover of persons within the wage distribution at the micro level to identify properties affecting wage mobility. I examine the wage position of individuals in the wage distribution which is divided into 100 wage percentiles, each percentile representing a rank. Finally, I look at the overall situation during 24 years (1984-2007) and the developments that have taken place over time. The main findings show that wage mobility has decreased over time, while inequality has increased. Mobility is highest in the middle section of the distribution and highest for persons aged 30- 
39 years. Individual upgrades in the wage distribution are more likely to occur for university graduates, younger workers and for persons working in the public sector, as well as for whitecollar workers and less likely for persons who faced an unemployment period in the time of observation. Wages are more volatile in the low-wage sector and for individuals moving downwards in the wage distribution.

I begin with a literature overview (chapter 2) and a description of the data set used for the empirical part: the SOEP from 1984 to 2007 (chapter 3). I then look at three stages of mobility: absolute mobility measured by real wage development (chapter 4), relative mobility measured by individual movement upwards or downwards in the wage distribution (chapter 5) and finally, the income risk associated with mobility measured by wage volatility (chapter 6). Chapter 7 concludes and gives a short outlook. While the main part of the paper focuses on males, an additional part in the appendix gives some insights into the situation for females.

\section{Literature}

There is evidence that well-being and happiness are not only affected by absolute wages but also by relative wages and the individual rank within the wage distribution. The first part of this chapter supports this approach using the argumentation of Brown et al. (2008) as a basis, while the second part reports empirical results of international comparative studies about wage mobility in Germany.

Textbook economics (e.g. Cahuc and Zylberberg, 2004, Franz, 2006) assume an individual utility function $\mathrm{u}$, depending on the absolute wage $\left(\mathrm{w}_{\mathrm{abs}}\right)$, hours $(\mathrm{h})$ worked, characteristics of the individual worker (i) and characteristics of the job (j).

$$
u=u\left(w_{a b s}, h, i, j\right)
$$

Based on this, some studies argue that it is not only the absolute wage, but also the relative wage that affects the utility, which is why individuals additionally compare their wages with the mean wage $\left(\mathrm{w}_{\text {mean }}\right)$ of a comparison group (see e.g. Clark and Oswald, 1996, Luttmer, 2005).

$$
u=u\left(w_{a b s}, w_{\text {mean }}, h, i, j\right)
$$


Based on the range frequency theory model (see Parducci, 1965, 1995), Brown et al. (2008) argue in a further step, that the ordinal position and the position within a wage distribution are also important. Individuals seem to be influenced by the end points and the variance of a wage distribution. Brown et al. (2008) use an empirical approach, using British labour data and, additionally, by conducting a laboratory experiment with students. In the experimental design, potential wages are arranged in such a manner that they create conceivable situations with the same utility, measured via equation (2) but with a different utility perception by the relevant individuals. The situation in Figure 1, where the utility of wages $\mathrm{X}$ and $\mathrm{Y}$ in distribution $\mathrm{A}$ and B measured via equation (2) is identical, provides an ostensive example. In nearly all experimental situations, the test subjects favoured distribution A for wage $\mathrm{Y}$ and distribution B for wage $\mathrm{X}$.

Figure 1: Hypothetical Wage Distributions

Distribution A

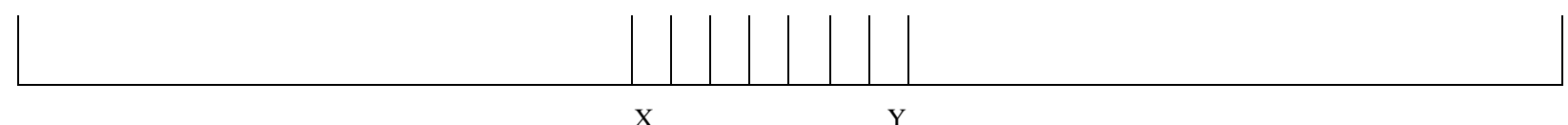

Distribution B

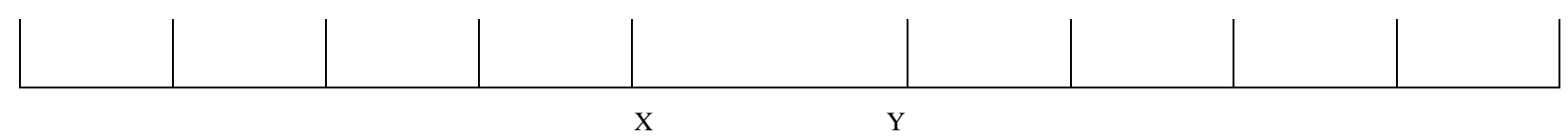

Source: Brown et al. (2008)

While wage $\mathrm{X}$ in distribution $\mathrm{B}$ has the same absolute amount as wage $\mathrm{X}$ in distribution $\mathrm{A}$, and the mean wage in both distributions is also identical, the individual utility in the lower distribution is higher because more persons face lower absolute wages (only one person in distribution A to four persons in distribution B). Thus, we need to expand the utility function by the range ( $\mathrm{w}_{\text {range }}$ ), measuring the position within the distribution and with the rank ( $\mathrm{w}_{\text {rank }}$ ), measuring the ordinal position in the wage distribution.

$$
u=u\left(w_{\text {abs }}, w_{\text {mean }}, w_{\text {rank }}, w_{\text {range }}, h, i, j\right)
$$

Thus, the rank of the individual in the wage distribution has a positive effect on individual utility, with higher ranks characterizing a higher position in the wage distribution. In the study at hand, ranks are measured via 100 wage percentiles. 
There exist some studies about wage mobility in Germany and in comparison with other countries. A first group compares Germany with the U.S. All studies in the group discussed here use the SOEP for Germany and the PSID for the U.S. as a data base. Higher mobility in the U.S. compared to Germany is established by van Kerm (2004), who looks at annual household income after tax and transfers between 1985 and 1997. Burkhauser et al. (1997) compare annual labour earnings mobility in Germany and in the U.S. in the 1980s. They report similar global mobility rates, as measured by quintile to quintile transition rates. Mobility is only higher for women in the U.S. In general, Burkhauser et al. (1997) report an “inverted-u” shape for mobility across initial wage quintiles. Jenkins and van Kerm (2006) for the period from 1985 to 1992, as well as Burkhauser and Poupore (1997) for the years 1983 to 1988 report a higher annual household net income mobility in Germany. Gottschalk and Spolaore (2002) analyse post tax and transfer family income between 1984 and 1993 and take a look at intergenerational family income mobility. They observe a higher mobility in Germany.

A second group compares Germany within Europe. The data base used in all of these studies is the European Community Household Panel (ECHP), the German part of this data set is based, once again, on the SOEP. Ayala and Sastre (2008) compare the mobility of the annual household income after tax and transfers for five European countries ${ }^{1}$, with Germany positioned below the mean. An expanded group of European countries ${ }^{2}$ is analysed by Pavlopoulos et al. (2008) and the European Commission (2004). Pavlopoulos et al. (2008) take a macroeconomically motivated look and try to explain the impact of economic conditions, welfare state regimes and employment regulation on wage mobility. For Germany, they determine a decreasing probability to move more than one decile in the annual labour earnings distribution between 1994/95 and 1999/00 - in other words, they find decreasing mobility. The study of the European Commission (2004) looks at gross hourly wages and establishes an average mobility in Germany. ${ }^{3}$ Sologon and O’Donoghue (2009) analyse the same 14 European countries using the ECHP for 1994 to 2001, focusing on real hourly wages for males born between 1940 and 1981. In their study mobility is measured by the ratio

\footnotetext{
${ }^{1}$ Spain, Great Britain, Italy, Germany, France.

2 Germany, Great Britain, Italy, Denmark, Luxembourg, Finland, the Netherlands, Ireland, Austria, Spain, Greece, Portugal, France and Belgium.

${ }^{3}$ They arrange the countries in 3 groups: High Mobility is observed in Great Britain, Luxembourg, Denmark and Finland; lowest mobility in Spain, Italy, Greece, Portugal, France and Belgium; and average mobility in the Netherlands, Germany, Ireland and Austria.
} 
between permanent and transitory ${ }^{4}$ inequality and they analyse the development and not the absolute amount of the wage mobility as the study from the European Commission (2004) did. Once again, they establish decreasing wage mobility during the observation period in Germany. ${ }^{5}$

A last group looks at the situation in Germany exclusively, focusing on the development over time. Uhlendorff (2006) looks at gross hourly wages from 1998 to 2003, using the SOEP. He analyses mobility between the conditions of high pay, low pay and no pay (unemployed), and finds a "low pay no pay" circle. Hauser and Fabig (1999), also using the SOEP from 1990 to 1995, compare income mobility, as measured by monthly gross and net individual labour income, between East and West Germany. They depict higher wage mobility in East Germany, in particular for the first years after unification. They argue that the tax and benefit system in Germany serves to reduce income mobility. Kaltenborn and Klös (2000) examine gross monthly labour income using the SOEP from 1984 to 1996 . They find that it is easier to move upwards than downwards, especially for younger people - another result of the study at hand. Low-wage earners also have a chance to leave this sector - a probability which increased between 1984 and 1996. Additionally, there are several short reports from the IAB, mostly written in German (e.g. Schank et al., 2009) which use official German Labour Data from the Agency of Labour. The main topics discussed here are the low-wage sector and potential minimum wages. Schank et al. (2009) use the administrative linked employeremployee data (LIAB) of the German Federal Employment Agency. They establish that only one out of eight employees who earned a low wage in 1998/99 left this sector in 2005. Younger and better qualified persons have a particularly good chance to move upwards, while women are less successful. Company size and job changes positively affect the chance to move upwards. While these results are exclusive for the low-wage sector, the study at hand confirms higher upward mobility for younger and better qualified employees and also for persons employed in larger firms over the whole wage distribution.

The paper at hand ties in with these studies by looking at a longer time period, using 24 waves of the SOEP from 1984 to 2007 and thus analysing wage mobility and development over time. The trend of decreasing wage mobility in Germany, reported in the literature so far, is

\footnotetext{
${ }^{4}$ Permanent earnings reflect personal characteristics, education and training while transitory earnings reflect factors which only affect earnings during a certain period, such as temporary shocks.

${ }^{5}$ And also decreasing mobility in Austria, France, Great Britain, Ireland, Luxembourg, Italy, Greece, Portugal and Finland while wage mobility increases in Denmark, Belgium, Spain and the Netherlands.
} 
confirmed. Moreover, the paper at hand will analyse individual socio-economic and environmental conditions for all persons of the wage distribution and their effect on wage mobility, as this has been lacking in the literature for Germany to the best of my knowledge. While most of the cited studies are restricted to males, I also analyse wage mobility for females in a separate section in the appendix.

The contribution of this empirical work is motivated by a paper by Raferzeder and WinterEbmer (2007) about wage mobility and mobility risk in Austria. I attempt to replicate their estimation design for Germany, thus the results are comparable. Additionally, the paper at hand exploits some advantage of the German data set (the SOEP), which allows to observe not only employment spells, but also periods of unemployment. Raferzeder and WinterEbmer (2007) use Austrian data for the period 1994-2001, concentrating on a balanced panel of males who were employed in every period under observation. The initial position in the wage distribution is important. The lower the starting position, the higher is the chance to move upwards in Austria. Moreover, wages are more volatile at the lower end of the distribution and most stable in the highest quintile. Workers in larger firms and white-collar employees are more likely to move upwards. Job changes increase an individual's wage mobility.

\section{Data}

The data base is the German Socio-Economic Panel (SOEP) from 1984 to 2007. The SOEP is a representative national longitudinal data set, which surveys households and individuals (Haisken-DeNew and Frick, 2005, Wagner et al., 2007). In 2007, there are about 11,000 households with more than 20,000 persons sampled in the SOEP. An advantage of this survey data compared to administrative data like the IABS, the LIAB or the data Raferzeder and Winter-Ebmer (2007) used is first, that wages are not censored by the social security contribution ceiling and so here it is possible to observe the whole wage distribution and second, the chance to calculate hourly wages and so it is possible to account for part-time employees on the one hand and overtime worked on the other hand.

I restrict the data to West-German males aged between 20 and 65 years who participate in the labour market. This procedure has been chosen for several reasons: Firstly, persons below 20 are often still in education and males older than 65 are normally retired. Secondly, the goal of 
this paper is to compare wage mobility over a long period of time. Before 1990, there were no observations of East-Germans in the SOEP and in the years after unification there existed an exceeding wage mobility caused by the transformation from a former socialistic economy to a capitalistic market economy. However, the analysis of this transformation is not the purpose of this paper. Thirdly, the main part focuses on males only because my aim is to compare these results to those of Raferzeder and Winter-Ebmer (2007). With regard to females, one would have to control for factors such as family situation and children, which are responsible for female career paths diverging from those of males. Despite that I use the advantage of the SOEP data and expand the approach by Raferzeder and Winter-Ebmer (2007), I do take a look at the situation for females in a separate step in the appendix, where I conduct the same analysis as for males. Moreover, I exclude persons who are still in the education system, interns, already retired persons, or those cooperating in a family business, because their wages, even if they are observed, are not comparable over time, particularly not with normal working periods. As output variable the real gross hourly wage is analysed. The hourly wage is obtained for all workers, including the self-employed, by dividing the gross wage in the month prior to the interview by the reported working hours of the last week, which are then extrapolated to monthly hours. I deflate all wages by the consumer price index to the price level of 2005 (source: Statistisches Bundesamt, 2008). To avoid problems of potential misreporting of hours worked and/or self-reported wages, I exclude all persons with hourly wages of less than $€ 1$ and more than $€ 100 .{ }^{6}$ For all analyses, I arrange the data in 4-year time periods (1984/1987, 1988/1991, 1992/1995, 1996/1999, 2000/2003, 2004/2007) and treat these periods as balanced panels. The challenge is to choose a time period which is not too short, in order to observe the development and adjustment processes for individuals. However, due to the design of the balanced panels, one loses observations via panel mortality with every further time period. 4-year periods seem to meet these two requirements. Thus it is possible to observe a wage, or at least an unemployment spell, for every person in every year.

A potential problem in analysing wage mobility lies in the selection into employment, in the sense that, particularly with regard to the low-wage sector, one observes wage changes for a positively selected group of workers who are employed at least at the beginning and the end of the observation period because only for these persons wages are observable in the data. Hence, decreases are only observable if the worker is still employed, but the transition to

\footnotetext{
${ }^{6}$ In 2004/2007 I lose 21 of 2,771 persons due to this restriction. In the other time periods it is about the same range.
} 
unemployment could also be registered as a form of wage reduction - to zero wages. ${ }^{7} 7.5 \%$ (2.8\%) of the low (high) wage workers in 2004 were unemployed in 2007. Nevertheless, the wage structure in this sense seems to be relatively stable; in all groups, the main part remains unchanged between 2004 and 2007 (see Table 1). In the other periods, there is some movement, especially from low-wage to high-wage (see Tables A1a-e in the appendix). In the data, the transition to unemployment is lowest in 1988/1991 and highest in 1992/1995. ${ }^{8}$ The low-wage barrier is defined as $2 / 3$ of the median in the 4-year time periods and is about $€ 11$ per hour in 2004/2007.

A look at the job status and the changes between 2004 and 2007 shows a relatively stable situation (see Table 2). Public sector employees in particular do not change their occupation, about $98 \%$ stay in their sector. Blue-collar, white-collar, or self-employed workers have persistent rates at approximately 85\% to 88\%. Being unemployed in 2004 provided the highest probability to leave this status compared to the other occupations and a switch to employment, mostly to the blue-collar sector, but hardly ever to the public sector. The situation in other periods is comparable to the one above (see Tables A2a-e in the appendix).

Table 1: Wage and Employment Status 2004 vs. 2007

\begin{tabular}{cl|ccc}
\hline \hline & & $\mathbf{2 0 0 7}$ & \\
& & Unemployed & Low-wage & High-wage \\
\hline \multirow{4}{*}{2004} & Unemployed & 133 & 59 & 34 \\
& & $(58.85 \%)$ & $(26.11 \%)$ & $(15.04 \%)$ \\
& Low-wage & 26 & 224 & 97 \\
& & $(7.49 \%)$ & $(64.55 \%)$ & $(27.95 \%)$ \\
& High-wage & 61 & 153 & 1963 \\
& & $(2.80 \%)$ & $(7.03 \%)$ & $(90.17 \%)$ \\
\hline \hline
\end{tabular}

Source: Samples from SOEP 1984-2007; own calculation, see text.

\footnotetext{
${ }^{7}$ Unemployment benefits are not included in wages.

${ }^{8}$ This is in line with the annual unemployment rates in West Germany: 8.1\% in 1984, 7.9\% in 1987, 7.9\% in $1988,5.9 \%$ in $1991,5.9 \%$ in $1992,8.1 \%$ in $1995,8.9 \%$ in $1996,8.6 \%$ in $1999,7.6 \%$ in 2000 , $8.4 \%$ in 2003 , 8.5\% in 2004 and 7.5\% in 2007 (Sachverständigenrat, 2008).
} 
Table 2: Job Status 2004 vs. 2007

\begin{tabular}{|c|c|c|c|c|c|c|}
\hline & & Unemployed & Blue-collar & $\begin{array}{c}2007 \\
\text { White-collar }\end{array}$ & $\begin{array}{l}\text { Public } \\
\text { Sector }\end{array}$ & $\begin{array}{c}\text { Self- } \\
\text { employed }\end{array}$ \\
\hline \multirow{5}{*}{2004} & Unemployed & $\begin{array}{c}133 \\
(58.85 \%)\end{array}$ & $\begin{array}{c}63 \\
(27.88 \%)\end{array}$ & $\begin{array}{c}20 \\
(8.85 \%)\end{array}$ & $\begin{array}{c}1 \\
(0.44 \%)\end{array}$ & $\begin{array}{c}9 \\
(3.98 \%)\end{array}$ \\
\hline & Blue-collar & $\begin{array}{c}43 \\
(4.66 \%)\end{array}$ & $\begin{array}{c}815 \\
(88.39 \%)\end{array}$ & $\begin{array}{c}52 \\
(5.64 \%)\end{array}$ & $\begin{array}{c}1 \\
(0.11 \%)\end{array}$ & $\begin{array}{c}11 \\
(1.19 \%)\end{array}$ \\
\hline & White-collar & $\begin{array}{c}35 \\
(3.10 \%)\end{array}$ & $\begin{array}{c}70 \\
(6.21 \%)\end{array}$ & $\begin{array}{c}993 \\
(88.03 \%)\end{array}$ & $\begin{array}{c}6 \\
(0.53 \%)\end{array}$ & $\begin{array}{c}24 \\
(2.13 \%)\end{array}$ \\
\hline & Public Sector & 0 & $\begin{array}{c}1 \\
(0.36 \%)\end{array}$ & $\begin{array}{c}3 \\
(1.08 \%)\end{array}$ & $\begin{array}{c}273 \\
(98.20 \%)\end{array}$ & $\begin{array}{c}1 \\
(0.36 \%)\end{array}$ \\
\hline & $\begin{array}{l}\text { Self- } \\
\text { employed }\end{array}$ & $\begin{array}{c}9 \\
(4.59 \%)\end{array}$ & $\begin{array}{c}8 \\
(4.08 \%)\end{array}$ & $\begin{array}{c}11 \\
(5.61 \%)\end{array}$ & 0 & $\begin{array}{c}168 \\
(85.71 \%)\end{array}$ \\
\hline
\end{tabular}

Source: Samples from SOEP 1984-2007; own calculation, see text.

\section{Absolute Mobility, Wage Development}

Before analysing rank mobility and volatility in detail, this chapter gives a short overview of the real gross hourly wage development from 1984 to 2007 for West-German males aged between 20 and 65 years. $^{9}$

Figure 2 shows the wage development difference between three percentiles $\left(10^{\text {th }}, 50^{\text {th }}\right.$ and $90^{\text {th }}$ percentile). While wages increase at the top of the distribution, wages are stable and even decrease from the mid-nineties on for the $10^{\text {th }}$ percentile, which can be identified as rising wage inequality. The real hourly wage at the $10^{\text {th }}$ percentile amounted to $€ 9.82$ in 1995 and then decreased to $€ 7.57$ in 2007 , representing a real wage loss of $25 \%$, while the wage at the $90^{\text {th }}$ percentile increased from $€ 24.56$ to $€ 26.90$ (plus $10 \%$ ) during the same time period. The real median wage remained fairly stable in this time, with a slight increase from $€ 14.41$ to $€$ $14.77^{10}$

\footnotetext{
${ }^{9}$ Data is restricted in the same way as described in the data section, with the exception of the 4-year balanced panel restriction, which is not necessary here.

${ }^{10}$ All wages are deflated to the 2005 price level.
} 
Figure 2: Wage Development From 1984-2007

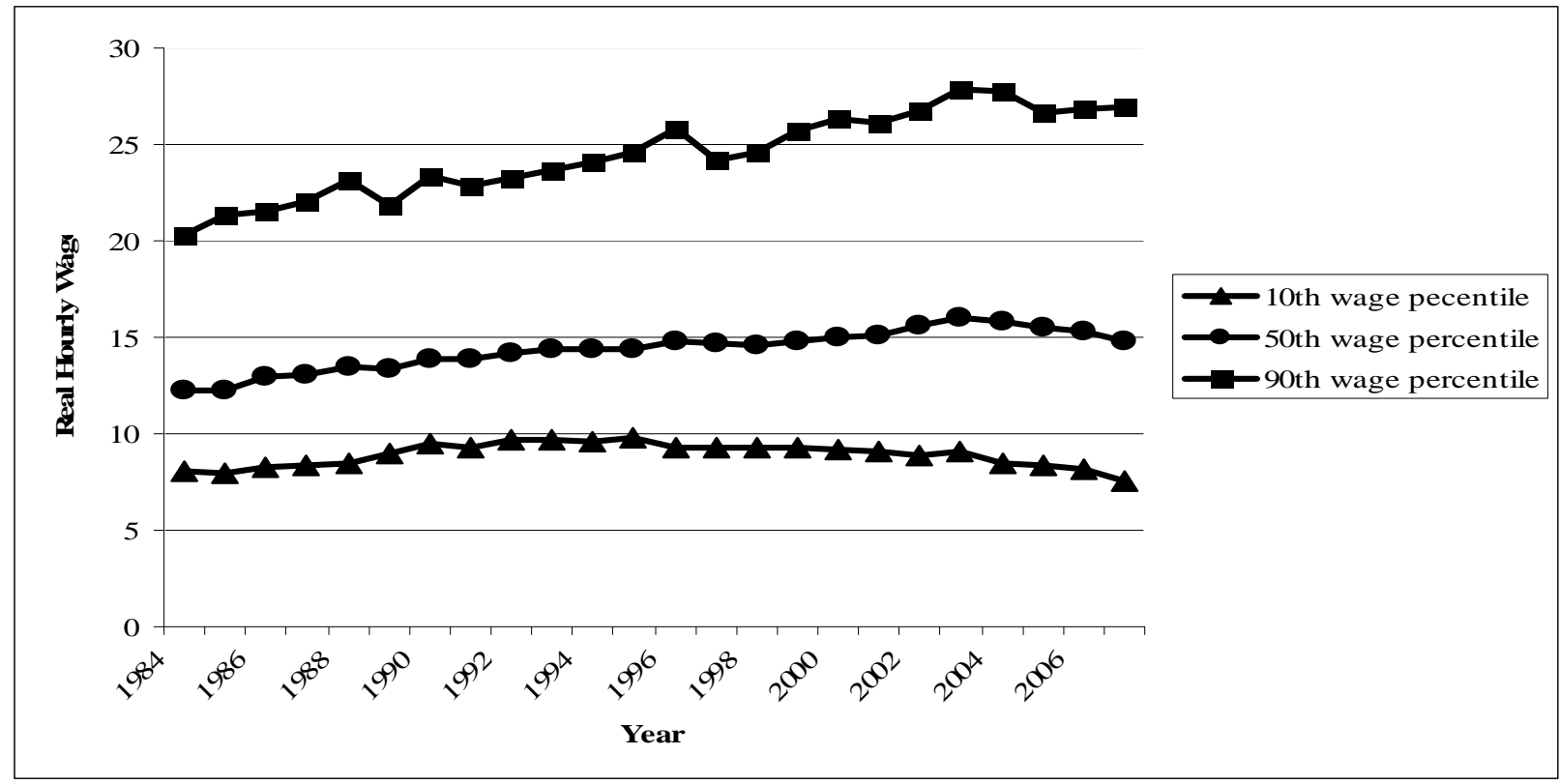

Source: Samples from SOEP 1984-2007; weighted data; own calculation, see text.

These findings suggest that wage inequality in Germany started to increase after the economic downturn in 1992/93 and also that wage mobility started to decrease (see Table 3 in the next chapter) - the ratio of the ninetieth to tenth percentile increased from 2.5 in 1995, to 3.1 in 2005, to 3.5 in 2007, while the standard deviation of rank differences as a proxy for mobility decreased from 21.51 in 1992/1995 to 17.06 in 2004/2007. This constitutes a stretching of the wage distribution, and chances for upward mobility are reduced.

\section{Wage Mobility}

Wage mobility is defined as the number of ranks through which a person moves between the start and the end year of a period. For example, if a person's wage is in percentile 20 in 2004 and in percentile 35 in 2007, there is an upward movement of 15 percentiles, or ranks, respectively. The difference varies, by definition, between plus 99 for a jump from the bottom to the top of the distribution and minus 99 for the opposite direction. In total, it is clear that for every person moving up in the relative wage distribution, there must be another person moving down, so the mean difference is around 0 . By definition, to observe this mobility measure there has to be a wage reported in the first year as well as in the last year. ${ }^{11}$ The 100 ranks are unequal concerning the range from the highest to the lowest wage. For example, in

\footnotetext{
${ }^{11}$ I tried to model the transfer into unemployment in the last year as a selection, via a two-step Heckman selection procedure. The result showed no selection at all, coefficients did not change, either. In addition, I allocated a fictive 0th percentile to all unemployed persons, and repeated the estimation. Once again, there was no evidence of a selection in unemployment.
} 
2004 the wages between $€ 1.07$ and $€ 5.26$ are attached to the first rank and wages between $€$ 50 and $€ 86.67$ to the highest rank. Anyhow, in the middle of the distribution the ranks are smaller. Hence the difference within the 8th and 95th rank is always below 5 percent, and for 31 out of these 87 ranks, the difference lies below 1 percent. These "small” ranks are distributed unsystematically all over the distribution and there are no more than three small ranks neighboured - thus there is no trend towards particular small ranks in the middle. ${ }^{12}$

Figure 3 gives an overview of this difference for the period between 2004 and 2007 (for all other periods, see Figures A3a-e in the appendix). The figures show a trend towards more compressed distributions over time. While there do exist some extreme values, $80 \%$ of the persons show wage leaps between minus 17 and plus 19 ranks with a mass point at zero. Table 3 gives an overview of the wage development, employment rates and the standard deviation of the wage rank difference - as a proxy for mobility. While median wages and also wage inequality increase, wage mobility decreases over time. The standard deviation was 22.66 between 1984 and 1987 and only 17.06 between 2004 and 2007. In 1992/1995 with 21.51 the standard deviation shows the second highest level, and this is also the period where wage inequality started to increase. Afterwards, the decrease from the mid-nineties till now is constant. Employment rates in the sample decrease slightly from 93\% to 89\%.

Figure 3: Earnings Mobility Between 2004 and 2007

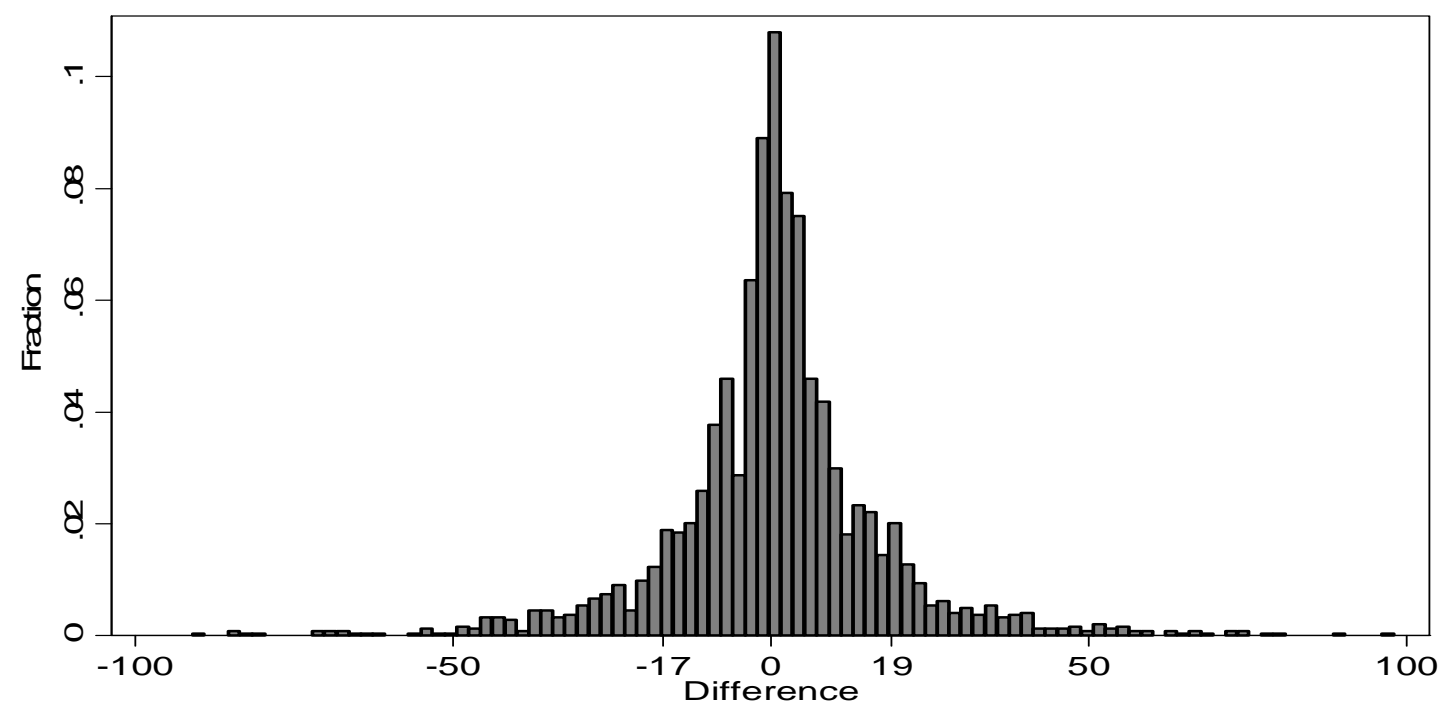

Source: Samples from SOEP 1984-2007; own calculation, see text.

\footnotetext{
${ }^{12}$ Ranks with a difference below $1 \%$ in 2004: 8, 14, 17, 20, 23-25, 27-28, 30, 32-33, 36-37, 39, 42-43, 48, 50-52, 54-55, 58, 60-62, 64-66, 71.
} 
Table 3: Mobility in Several Time Periods

\begin{tabular}{lcccc}
\hline \hline Time Period & $\begin{array}{c}\text { Yearly } \\
\text { Observations } \\
\text { (Balanced Panel) }\end{array}$ & $\begin{array}{c}\text { Employment } \\
\text { Rate }\end{array}$ & $\begin{array}{c}\text { Real Gross } \\
\text { Hourly Wage, } \\
\text { Median }\end{array}$ & $\begin{array}{c}\text { Standard Deviation of } \\
\text { Rank Differences, } \\
\text { Mobility }\end{array}$ \\
\hline $\mathbf{2 0 0 4 - 2 0 0 7}$ & 2,750 & 0.89 & 16.11 & 17.06 \\
$\mathbf{2 0 0 0 - 2 0 0 3}$ & 2,900 & 0.91 & 16.02 & 18.94 \\
$\mathbf{1 9 9 6 - 1 9 9 9}$ & 1,986 & 0.91 & 15.18 & 19.75 \\
$\mathbf{1 9 9 2 - 1 9 9 5}$ & 1,831 & 0.91 & 14.75 & 21.51 \\
$\mathbf{1 9 8 8 - 1 9 9 1}$ & 2,006 & 0.94 & 14.09 & 20.77 \\
$\mathbf{1 9 8 4 - 1 9 8 7}$ & 1,910 & 0.93 & 13.04 & 22.66 \\
\hline \hline
\end{tabular}

Source: Samples from SOEP 1984-2007; weighted data; own calculation, see text.

After documenting these stylized facts, the next and even more interesting questions are: What drives wage mobility? Are special groups predetermined for relative wage gains or losses? Does every employee in Germany have the same opportunities, e.g. is the "American Dream” possible; to turn from dishwasher to millionaire?

Tables 4 and A4 in the appendix show the relation of explaining variables like age, age squared, the starting wage percentile, industry, occupation, job changes, firm size, unemployment, job status and migration background on the chances and the extent of a jump within ranks in the relative wage distribution between the start and the end year. The first column of Table 4 shows the results for the latest observable time period (2004/2007), the second column is a subsample of these data, restricted only to prime age dependent and always employed persons (PADAE) for a sensitivity check, the third column shows the results for 1992/1995 and the fourth column the results for the first period observable in the SOEP data (1984/1987). Like Raferzeder and Winter-Ebmer (2007), I adapt a simple ordinary least squares regression technique to do this. For the possibility and the extent of a jump, the starting position is important. Hence, I control for all percentiles (results are not reported in Table 4 but are portrayed graphically in Figure 4). The results are not surprising; starting at the bottom the only possibility is to remain in the same place or to move upwards and the opposite applies to those positioned at the top of the distribution (see Figure 4). 
Figure 4: Coefficients for the Wage Percentiles 2004/2007, Base Category: $50^{\text {th }}$ Percentile

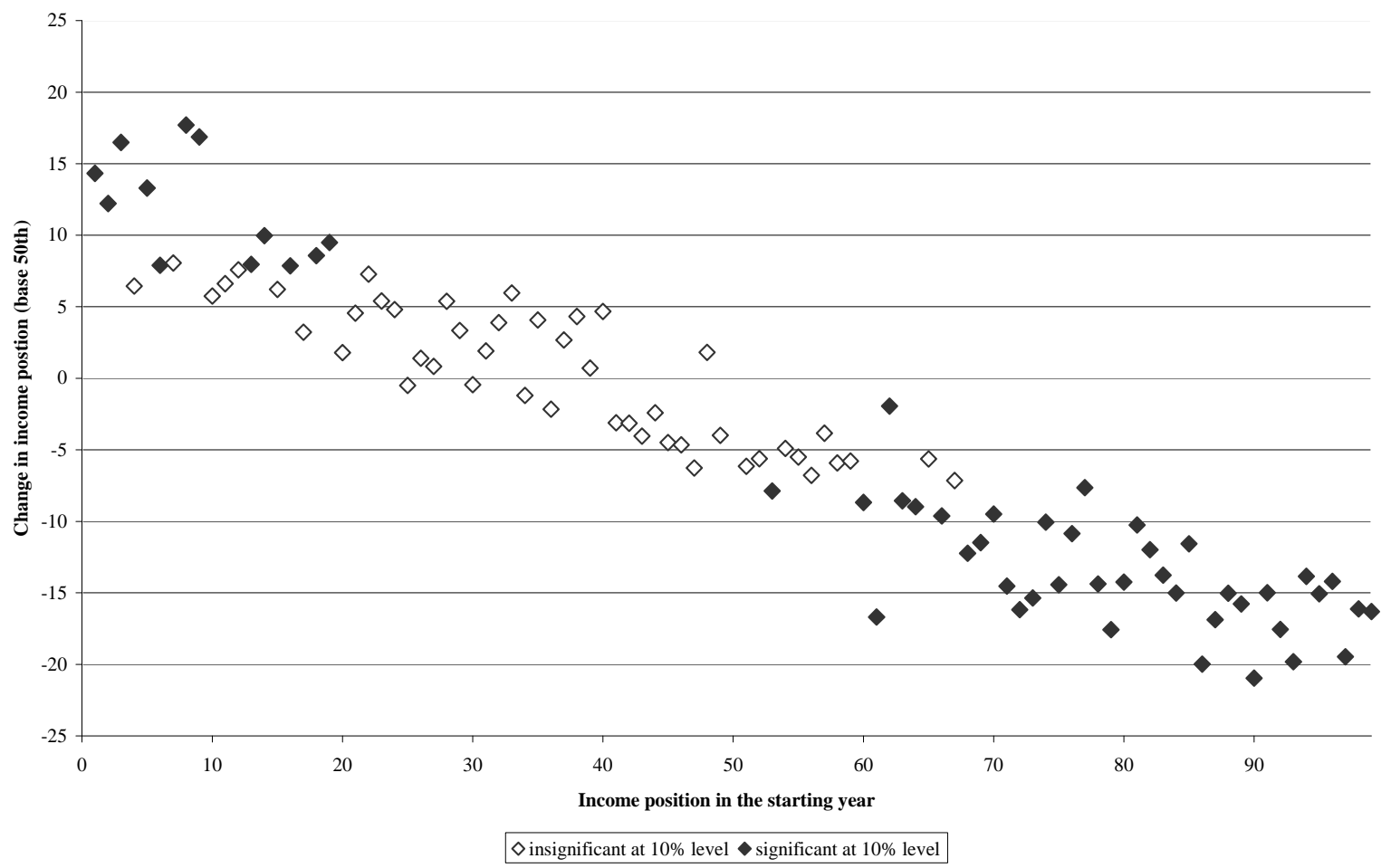

Source: Samples from SOEP 1984-2007, Reference category is the $50^{\text {th }}$ wage percentile.

Positive jumps are particularly common for persons in their thirties. The coefficient of 2.31 for the period 2004/2007 shows that, compared to the reference group of persons above the age of 50, persons aged between 30 and 39 years move an average of 2.31 ranks upwards in the wage distribution compared to the reference group - not necessarily at the cost of the older groups. Persons who have an academic education defined as a university or technical college degree also have higher chances of climbing up the relative wage distribution by about 4 ranks in 2004/2007.

With regard to industries and occupations, there is a clear picture: industries making high demands on their employees also seem to provide better opportunities of upgrading the individual position in the wage distribution. The same holds true for occupations. Here the highest chances of moving upwards are observed for professionals, while elementary occupations lead to a downward move of 8 ranks compared to professionals. This is the same tendency for all time periods from 1984 onwards while effects are more pronounced in earlier periods. 
The effect of a job change is inconclusive. In general, the opportunity of moving upwards is higher in larger firms. Working in a firm with more than 200 employees increases the chances of moving upwards significantly, by about two and a half ranks, compared to workers with less than 19 colleagues. An unemployment disruption between the start and the end year has a high negative conjunction on the flow. Unemployment in the second year (e.g. 2005 in the period 2004/2007) leads to downward movement of 9.80 ranks and unemployment in the third year (e.g. 2006 in the period 2004/2007) to a downward movement of 16.29 in contrast to the reference group of employed persons, in other words, unemployment in both middle years leads to a downward movement of about 25 ranks in the time period 2004/2007. Job status also has a significant effect on mobility. Compared to blue-collar workers, the chances of moving upwards in the period 2004/2007 are higher for white-collar workers (3.57 ranks), for employees of the public sector (5.18 ranks) and for self-employed persons (7.60 ranks). Migration background has no significant effect in the time period of 2004/2007.

For a sensitivity check, I restrict the group of interest to dependent employees of prime age (25-55 years), who are employed throughout all periods (reported only for 2004/2007). The relation of the variables (now excluding by definition unemployment and self-employment) on the change in the relative income distribution does not change - the 95 percent confidence intervals overlap (not reported in the table), see the second column in Table 4.

Results for other time periods are in line and show, with a few exceptions, the same direction (Table 4 and Table A4 in the appendix). While the job status and industry sector is not significant in early periods, the migrational background significantly leads to a downwards slip of the wage distribution of 5.77 ranks in 1984/1987 and 2.74 ranks in 1992/1995. In all years, an academic education leads to significantly higher chances of upward movement but the impact of the effect is highest in 1984/1987 with 9.38 ranks, decreases to 2.78 in 2000/2003 and then increases again to 4.26 in the last period but is still only about half as strong compared to the beginning. One reason for this could be the increasing supply of academically trained workers in this time caused by the so-called educational expansion in Germany beginning in the 1960s. 
Table 4: Change in Relative Income Position

\begin{tabular}{|c|c|c|c|c|}
\hline & $2004 / 2007$ & $\begin{array}{c}\text { 2004/2007 } \\
\text { PADAE }\end{array}$ & 1992/ 1995 & $1984 / 1987$ \\
\hline Wage Percentile (Starting Year) (Base: 50th) & $\mathrm{nr}$ & $\mathrm{nr}$ & $\mathrm{nr}$ & $\mathrm{nr}$ \\
\hline \multicolumn{5}{|l|}{ Age (Base: 50-) } \\
\hline-29 & -1.15 & -1.63 & 1.31 & -0.55 \\
\hline $30-39$ & $2.31 * * *$ & 1.52 & 2.10 & $3.21 * *$ \\
\hline $40-49$ & 1.08 & 0.75 & 1.89 & $3.14 * *$ \\
\hline Academic Education & $4.26 * * *$ & $4.59 * * *$ & $6.12 * * *$ & $9.38 * * *$ \\
\hline \multicolumn{5}{|l|}{ Industry (Base: Administration, Education) } \\
\hline High-tech Industry & $4.26 * * *$ & $5.06 * * *$ & 0.32 & $4.49 *$ \\
\hline Traffic, Distribution & $3.88 * *$ & $4.59 * * *$ & -3.97 & -3.17 \\
\hline Financial Services & $4.08 * *$ & $5.15 * * *$ & -0.26 & $7.60 * *$ \\
\hline Others & $\mathrm{nr}$ & $\mathrm{nr}$ & $\mathrm{nr}$ & $\mathrm{nr}$ \\
\hline \multicolumn{5}{|l|}{ Occupation (Base: Professionals) } \\
\hline Clerks & $-5.38 * * *$ & $-5.45 * * *$ & $-5.58 * *$ & $-6.57 * *$ \\
\hline Service Workers & $-7.37 * * *$ & $-6.33 * * *$ & $-8.70 * *$ & $-9.53 * *$ \\
\hline Craft Workers & $-6.34 * * *$ & $-6.81 * * *$ & $-8.46 * * *$ & $-5.41 *$ \\
\hline Plant and Machine Operators & $-7.72 * * *$ & $-8.08 * * *$ & $-10.29 * * *$ & $-8.00 * *$ \\
\hline Elementary & $-7.98 * * *$ & $-8.30 * * *$ & $-10.79 * * *$ & $-11.30 * * *$ \\
\hline Others & $\mathrm{nr}$ & $\mathrm{nr}$ & $\mathrm{nr}$ & $\mathrm{nr}$ \\
\hline \multicolumn{5}{|l|}{ Job Change in } \\
\hline Year 1 & -0.08 & -1.15 & -1.65 & - \\
\hline Year 2 & $-2.34 *$ & -1.68 & 2.46 & -0.22 \\
\hline Year 3 & 1.58 & 2.13 & -3.87 & -1.82 \\
\hline Year 4 & -2.03 & -0.91 & 1.79 & - \\
\hline \multicolumn{5}{|l|}{ Firm Size (Base -19) } \\
\hline 20-199 & 0.27 & 0.13 & 1.43 & $3.20 *$ \\
\hline 200-1999 & $2.74 * *$ & $2.48 * *$ & 1.02 & $6.40 * * *$ \\
\hline $2000-$ & $2.59 * *$ & $2.72 * *$ & 2.79 & $9.19 * * *$ \\
\hline \multicolumn{5}{|l|}{ Unemployed in } \\
\hline Year 2 & $-9.80 * * *$ & - & -7.39 & -4.17 \\
\hline Year 3 & $-16.29 * * *$ & - & $-12.60 * * *$ & -6.08 \\
\hline \multicolumn{5}{|l|}{ Job Status (Base: Blue-collar) } \\
\hline White-collar & $3.57 * * *$ & $3.01 * *$ & $3.22 *$ & $5.96 * * *$ \\
\hline Public sector & $5.18 * * *$ & $4.69 * *$ & -1.84 & 2.72 \\
\hline Self-employed & $7.60 * * *$ & - & -3.80 & 5.41 \\
\hline Migration Background & 0.32 & -0.31 & $-2.74 * *$ & $-5.77 * * *$ \\
\hline Constant & 0.84 & 1.16 & 4.43 & 19.12 \\
\hline $\mathbf{N}$ & 2,291 & 1,871 & 1,497 & 1,486 \\
\hline Adj. R-squared & 0.21 & 0.19 & 0.25 & 0.33 \\
\hline
\end{tabular}

Source: Samples from SOEP 1984-2007; nr - results not reported in the table; PADAE - Prime age dependent (in starting year) and always employed; Others - all other groups are separately accounted for in the estimation; *** - significant at the $1 \%$ level, ** - at the $5 \%$ level, * - at the $10 \%$ level; own calculation, see text.

Comparisons between countries are difficult because the amount of the wage inequality influences the absolute borders of the percentiles. Hence, in countries with a narrow wage distribution, smaller absolute wage changes are necessary to move several relative wage percentiles. Overall, the OECD (2008a) reports a $90^{\text {th }}$ to $10^{\text {th }}$ wage percentile ratio of 3.27 for Austria and 3.98 for Germany in the 2000s, so the wage distribution is more compressed in Austria. Nevertheless, it is feasible to compare the results at hand with those of Raferzeder and Winter-Ebmer (2007) for Austria between 1994 and 2001. They use the same methodical approach as does the study at hand. The most significant predictors for upward mobility in 
Austria are age, education, and the status at the beginning of the period. In Austria, the youngest workers (below 29) have the highest chances of moving upwards (plus 12 ranks), in Germany the highest chances are observed in the older group of males aged 30-39 years. This could be caused by an earlier entry to the labour market in Austria. While the amount of tertiary educated persons is comparable in both countries, persons are aged between 22 and 26 in Austria and 24 to 27 in Germany when they graduate (OECD, 2008b) and so Austrians face a higher job experience in earlier ages. Academic education also leads to an upgrade of 6 ranks, comparable to the situation in Germany. Firm size also has the same effect as in Germany - larger firms offer better opportunities of moving upwards. Likewise, the status at the beginning of the period tells the same story as in Germany, a start at the bottom offers higher chances of moving upwards, despite that Raferzeder and Winter-Ebmer (2007) only control for wage quartiles in Austria. A disadvantage of the Austrian study is that unemployment spells are not included in the data set and so no comparison of the results concerning this point is possible.

\section{Wage Volatility}

The next logical step would be to ask how stable these jumps are in the wage distribution. How much volatility is there? Volatility measures the wage fluctuations occurring during a period of four years, e.g. between 2004 and 2007. One has to bear in mind that here wage volatility is measured in terms of rank positions. ${ }^{13}$ Thus, it could be possible for a person to start and end in the same rank, in this case one would observe no mobility, but rather, jumps in the wage distribution within the period, which is defined as volatility here. Volatility could be interpreted as a proxy for insecurity with potential impact on some long lasting investment decisions such as education or family planning - it thus captures the more negative side of earnings mobility, especially if one assumes that employees are risk averse, which seems plausible (see Kihlstrom and Laffont, 1979).

To measure volatility one has to sum up the absolute (abs) rank change (rc) of the wage distribution in the 4-year period (e.g. for 2004/2007: 2004 to 2005, 2005 to 2006 and 2006 to

\footnotetext{
${ }^{13}$ So changes in the upper part of the distribution require a larger change of absolute wage compared to the bottom of the distribution because wage percentiles, and therefore ranks in my definition, are more expanded at the top. This was also discussed in more detail at the beginning of the last chapter and does not seem to be a general problem.
} 
2007) plus 1 and divide it by the absolute rank change between the start and the end year (e.g. for 2004/2007: 2004 to 2007) plus 1.

(4)

$$
\text { Volatility }=\frac{1+\sum_{t=2005}^{2007} a b s\left(r c_{t}-r c_{t-1}\right)}{1+a b s\left(r c_{2007}-r c_{2004}\right)}
$$

By definition, wage volatility must be at least 1 for showing no volatility. For the period of 2004/2007, I observe values ranging from 1 to 193. Higher values represent higher wage volatility. Volatility is equal to 1 if wage development in the time period (e.g. between 2004 and 2007) maintains the same direction or occurs only in one year. Volatility is also 1 if there is no wage mobility in the sense that the individual rank is the same in every year.

Figure 5 shows the distribution of the log volatility for the period 2004/2007 (for all other periods, see Figure A5a-e in the appendix). About 20\% of the persons in the sample at hand face no volatility.

In Germany volatility is highest in the first period 1984/1987, then decreases, increases again in the period of an economic downturn in 1992/1995 and then stabilizes between 4 and 4.2. Persons with downward mobility are affected by a higher volatility than persons moving upwards in all periods, the only exception being the period 2000/2003. This means that the way down is more volatile while the way up is more straightforward. On comparing low-wage earners and the rest of the employees, there seems to be higher volatility in the low-wage sector with one exception in 1988/1991 (see Table 5).

Table 5: Volatility in 4-year Periods

\begin{tabular}{lcccccc}
\hline \hline & $\mathbf{8 4 / 8 7}$ & $\mathbf{8 8 / 9 1}$ & $\mathbf{9 2 / 9 5}$ & $\mathbf{9 6 / 9 9}$ & $\mathbf{0 0 / 0 3}$ & $\mathbf{0 4 / 0 7}$ \\
\hline Overall & 4.85 & 4.08 & 4.56 & 4.01 & 4.19 & 4.17 \\
\hline Low-wage & 5.41 & 3.81 & 5.83 & 4.59 & 4.76 & 4.77 \\
High-wage & 5.12 & 4.36 & 4.30 & 4.18 & 4.08 & 4.12 \\
\hline Moving Upwards & 3.89 & 3.66 & 3.70 & 3.30 & 3.84 & 3.50 \\
Moving Downwards & 4.67 & 4.01 & 4.33 & 4.02 & 3.57 & 3.74 \\
\hline \hline
\end{tabular}

Source: Samples from SOEP 1984-2007; own calculation, see text. 
Figure 5: Log. Wage Volatility 2004-2007

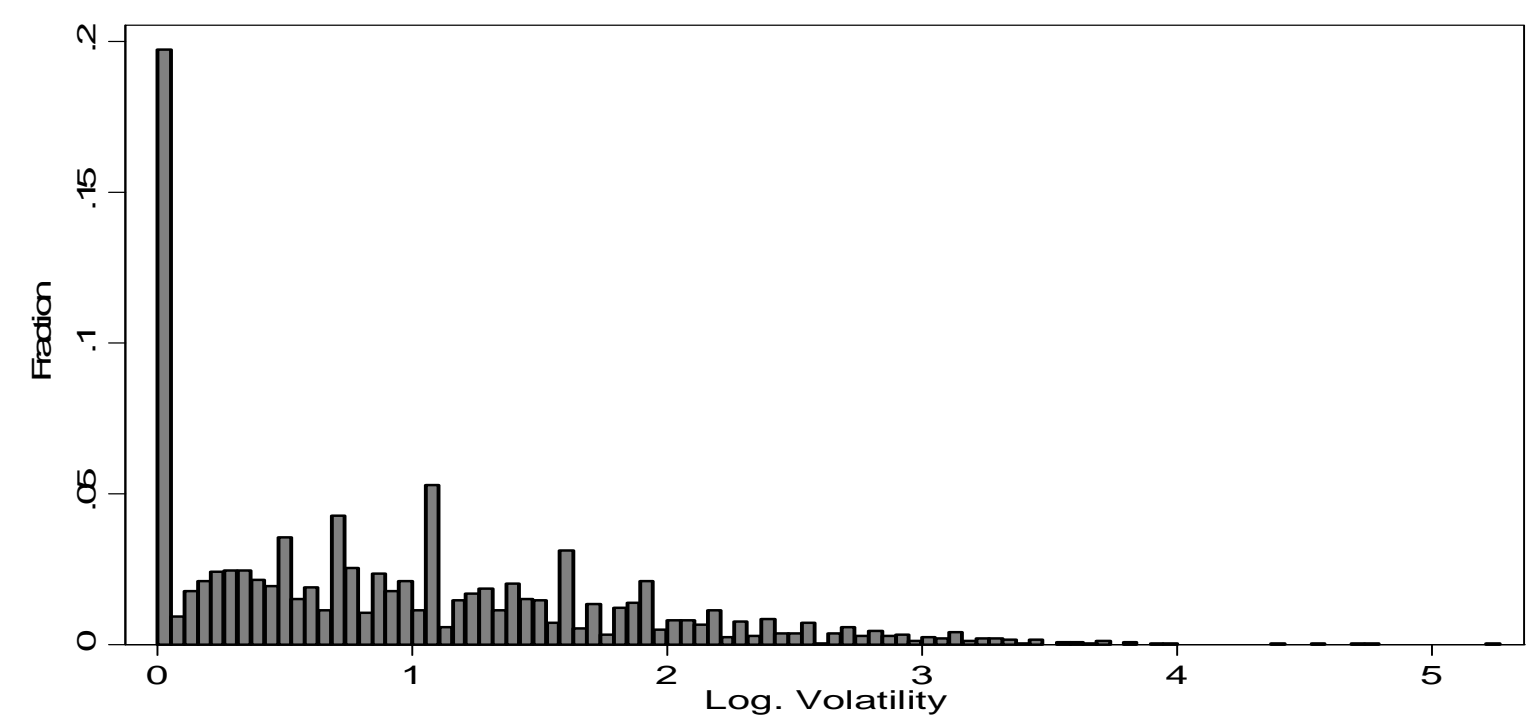

Source: Samples from SOEP 1984-2007; own calculation, see text.

Once again, results are compared with those of the Austrian study by Raferzeder and WinterEbmer (2007). In Austria, workers in the lowest income quartiles face the highest earnings volatility over time - this result is in line with the findings of this paper for Germany. The authors further assume that higher volatility in this lower part is mainly caused by persons who climb the job ladder, which does not seem to be the case for Germany, as the study at hand observes a higher volatility for persons moving downward. For the U.S., Shin and Solon (2008) report that earnings volatility is countercyclical with a higher volatility during the recession, a finding that is in line with the results for Germany if one identifies the period of 1992/1995 as a recession period. Earnings volatility for male workers increased during the 1970s, showed no clear tendency afterwards and increased again in the 2000s in the U.S.

\section{Conclusion}

The study at hand takes a look at wage mobility and volatility as measured by individual ranks in the wage distribution. In addition to the absolute wage and the mean wage in a group, the relative position within the wage distribution also affects an individual's well-being and thus constitutes a further component in a wider defined utility function. Higher mobility could diminish the effects of rising wage inequality.

The empirical results are based on SOEP data which has the advantage, among others, of allowing one to observe unemployment periods. It is these unemployment periods between 
jobs in particular that are responsible for downward mobility. In Germany, individual wage mobility decreased between 1984/1987 and 2004/2007, particularly after the economic downturn in 1992/1993. Wage inequality, however, has increased steadily from this time onwards. Hence, it seems that changes in wage mobility intensify cross-section inequality, which potentially leads to even higher life time inequality or in other words, as the wage distribution widens, the individual's mobility is reduced.

Mobility is highest in the middle section of the distribution, while wages seem to be more stable at the bottom and the top of the distribution. Mobility is highest for persons aged between 30-39 years. Individual upgrades in the wage distribution are more likely to occur for younger workers and for persons working in the public sector, as well as for white-collar workers and persons with academic education. Overall wage volatility decreases and wages are more volatile in the low-wage sector and for individuals moving downwards in the wage distribution.

This could be of political interest as persons who are discouraged or even concerned about their future chances may not invest optimally into their human capital. On the other hand, the results show that education is still a means of moving upwards via an academic degree or indirectly by working in a professional occupation or outside the blue-collar sector, which motivates individuals to embark on further education in order to progress upwards. Another point is that of the mere subjective feeling of unfairness can lead to confusion and concern in a society. Thus, politics are obliged to offer equal chances for everyone. An indicator for such chances could be wage mobility, particularly in times of rising wage inequality.

Further empirical research for the time period after the economic recession in 2008/2009 on the effects of the crisis on wages, particularly with regard to inequality and mobility would be highly interesting. Moreover, the reforms of the German labour market (e.g. Hartz IV from January 2005 on) with effects especially in the low wage sector are potentially better to identify in new data waves; particularly with regard to wage mobility over time for persons affected by these treatments. This would provide insight into whether these persons are locked in the low-wage sector or whether the reform chances allow for a new start in the labour market, thus enabling them to leave the low-wage sector after some time. 


\section{Bibliography}

Acemoglu, D. (2002), Technical Change, Inequality, and the Labor Market, Journal of Economic Literature 40 (1), 7-72.

Acemoglu, D. (2003), Cross-Country Inequality Trends, The Economic Journal 113 (485), F121-F149.

Autor, D.H., L.F. Katz, M.S. Kearney (2008), Trends in U.S. Wage Inequality: Revising the Revisionists, Review of Economics and Statistics 90 (2), 300-323.

Ayala, L., M. Sastre (2008), The structure of income mobility: empirical evidence from five UE countries, Empirical Economics 35 (3), 451-473.

Brown, G.D.A., J. Gardner, A.J. Oswald, J. Qian (2008), Does Wage Rank Affect Employees’ Well-being, Industrial Relations 47 (3), 355-389.

Burkhauser, R.V., D. Holtz-Eakin, S.E. Rhody (1997), Labor Earnings Mobility and Inequality in the United States and Germany During the Growth Years of the 1980s, International Economic Review 38 (4), 775-793.

Burkhauser, R.V., J.G. Poupore (1997), A Cross-National Comparison of Permanent Inequality in the United States and Germany, The Review of Economics and Statistics 79 (1), 10-17.

Cahuc, P., A. Zylberberg (2004), Labor Economics, MIT Press.

Clark, A.E., P. Frijters, M.A. Shields (2008), Relative Income, Happiness, and Utility: An Explanation for the Easterlin Paradox and Other Puzzles, Journal of Economic Literature 46 (1), 95-144.

Clark, A.E., A.J. Oswald (1996), Satisfaction and comparison income, Journal of Public Economics 61, 359-381.

Cornelißen, T., O. Hübler (2008), Downward wage rigidity and job mobility, Empirical Economics 34 (2), 205-230.

DiNardo, J., N.M. Fortin, T. Lemieux (1996), Labor Market Institutions and the Distribution of Wages, 1973-1992: A Semiparametric Approach, Econometrica 64 (5), 1001-1044.

Dustmann C., J. Ludsteck, U. Schoenberg (2009), Revisiting the German Wage Structure, Quarterly Journal of Economics 124 (2), 843-881.

Easterlin, R.A. (1974), Does Economic Growth Improve the Human Lot? Some Empirical Evidence, in: R. David, M. Reder (eds.), Nations and Households in Economic Growth: Essays in Honor of Moses Abramovitz, New York, 89-125.

Easterlin, R.A. (1995), Will Raising the Incomes of All Increase the Happiness of All?, Journal of Economic Behavior and Organisation 27 (1), 35-47. 
Eisenhauer, P., F. Pfeiffer (2008), Assessing Intergenerational Earnings Persistence Among German Workers, Journal of Labour Market Research 2\&3, 119-137.

Eurropean Comission (2004), Employment in Europe, Brussels.

Franz, W. (2006), Arbeitsmarktökonomik, Springer, Heidelberg.

Gernandt, J., F. Pfeiffer (2007), Rising Wage Inequality in Germany, Jahrbücher für Nationalökonomie und Statistik 227 (4), 358-380.

Gottschalk, P., E. Spolaore (2002), On the Evaluation of Economic Mobility, Review of Economic Studies 69 (1), 191-208.

Haisken-DeNew, J., J.R. Frick (2005), DTC Desktop Companion to the German SocioEconomic Panel (SOEP), DIW Berlin.

Hauser, R., H. Fabig (1999), Labor Earnings and Household Income Mobility in Reunified Germany: A Comparison of the Eastern and Western States, Review of Income and Wealth 45 (3), 303-324.

Jenkins, S.P., P. van Kerm (2006), Trends in income inequality, pro poor income growth, and income mobility, Oxford Economic Papers 58 (3), 531-548.

Kaltenborn, B., H.-P. Klös (2000), Arbeitsmarktstatus und Lohnmobilität in Westdeutschland 1984/96, iw-trends 27 (2), 24-45.

Kerm, P. van (2004), What Lies Behind Income Mobility? Reranking and Distributional Change in Belgium, Western Germany and the USA, Economica 71 (282), 223-239.

Keynes, J.M. (1936), The General Theory of Employment, Interest and Money, New York.

Kihlstrom, R.E., J.-J. Laffont (1979), A General Equilibrium Entrepreneurial Theory of Firm Formation Based on Risk Aversion, The Journal of Political Economy 87 (4), 719-748.

Kohn, K. (2006), Rising Wage Dispersion, After All! The German Wage Structure at the Turn of the Century, ZEW DP 06-031.

Luttmer, E.F.P. (2005), Neighbors as Negatives: Relative Earnings and Well-being, The Quarterly Journal of Economics 120 (3), 963-1002.

OECD (2008a), Growing Unequal? Income Distribution and Poverty in OECD Countries, OECDpublishing Paris.

OECD (2008b), Education at a Glance 2008, OECDpublishing Paris.

Parducci, A. (1965), Category Judgment: A Range-frequency Theory, Psychological Review 72, 407-418.

Parducci, A. (1995), Happiness, Pleasure, and Judgment: The Contextual Theory and its Application, Mahwah, New York. 
Pavlopoulos, D., R. Muffels, J.K. Vermunt (2008), Wage Mobility in Europe. A Comparative Analysis Using restricted Multinominal Logit Regression, Quality and Quantity online.

Pfeiffer, F. (2003), Lohnrigiditäten im gemischten Lohnbildungssystem, ZEW Wirtschaftsanalysen, Bd. 65, Baden-Baden.

Raferzeder, T., R. Winter-Ebmer (2007), Who is on the rise in Austria: Wage mobility and mobility risk, Journal of Economic Inequality 5 (1), 39-51.

Sachverständigenrat (2008), Jahresgutachten 2008/09: Die Finanzkrise meistern Wachstumskräfte stärken, Wiesbaden.

Schank, T., C. Schnabel, J. Stephani (2009), Geringverdiener. Wem und wie gelingt der Aufstieg? Jahrbücher für Nationalökonomie und Statistik (forthcoming).

Shin, D., G. Solon (2008), Trends in Men's Earnings Volatility: What Does the Panel Study of Income Dynamics Show? NBER WP 14075.

Sologon, D.M., C. O’Donoghue (2009), Earnings Dynamics and Inequality among Men across 14 EU Countries, 1994-2001: Evidence from ECHP, IZA DP 4012.

Solon, G. (1992), Intergenerational Income Mobility in the United States. The American Economic Review 82 (3, :393-408.

Statistisches Bundesamt (2008), Statistisches Jahrbuch 2008 für die Bundesrepublik Deutschland, Wiesbaden.

Summers, L. (1988), Relative Wages, Efficiency Wages, and Keynesian Unemployment, The American Economic Review 78 (2) P\&P, 383-388.

Uhlendorff, A. (2006), From No Pay to low Pay and Back Again? A Multi-State Model of Low Pay Dynamics, IZA DP 2482.

Wagner, G.G., J.R. Frick, J. Schupp (2007), The German Socio-Economic Panel Study (SOEP) - Scope, Evolution and Enhancements, SOEPpapers 1. 


\section{Appendix}

Table A1a: Wage and Employment Status 2000 vs. 2003

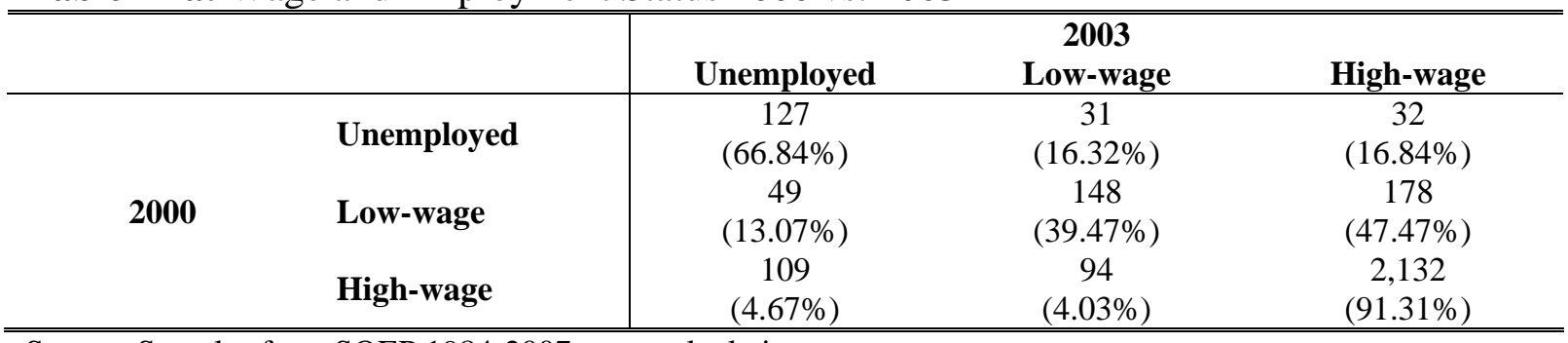

Source: Samples from SOEP 1984-2007; own calculation, see text.

Table A1b: Wage and Employment Status 1996 vs. 1999

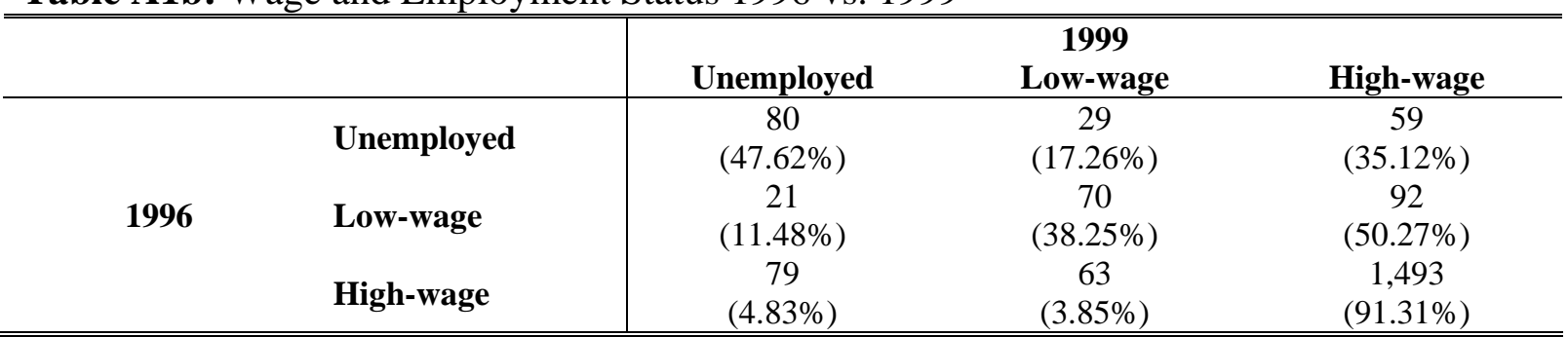

Source: Samples from SOEP 1984-2007; own calculation, see text.

Table A1c: Wage and Employment Status 1992 vs. 1995

\begin{tabular}{cc|ccc}
\hline & & 1995 & High-wage \\
\hline \multirow{3}{*}{1992} & Unemployed & Unemployed & 66 & 19 \\
& & $(70.97 \%)$ & $(8.60 \%)$ & $(20.43 \%)$ \\
& Low-wage & 16 & 40 & 68 \\
& & $(12.90 \%)$ & $(32.26 \%)$ & $(54.84 \%)$ \\
& High-wage & 105 & 44 & 1,465 \\
& & $(6.51 \%)$ & $(2.73 \%)$ & $(90.77 \%)$ \\
\hline \hline
\end{tabular}

Source: Samples from SOEP 1984-2007; own calculation, see text.

Table A1d: Wage and Employment Status 1988 vs. 1991

\begin{tabular}{cl|ccc}
\hline \hline & & 1991 & High-wage \\
\hline \multirow{4}{*}{1988} & Unemployed & Unemployed & 13 & 55 \\
& & $(49.63 \%)$ & $(9.63 \%)$ & $(40.74 \%)$ \\
& Low-wage & 2 & 37 & 122 \\
& & $(1.24 \%)$ & $(22.98 \%)$ & $(75.78 \%)$ \\
& High-wage & 52 & 38 & 1,620 \\
& & $(3.04 \%)$ & $(2.22 \%)$ & $(94.74 \%)$ \\
\hline \hline
\end{tabular}

Source: Samples from SOEP 1984-2007; own calculation, see text. 
Table A1e: Wage and Employment Status 1984 vs. 1987

\begin{tabular}{cl|ccc}
\hline \hline & & 1987 & High-wage \\
\hline \multirow{2}{*}{1984} & Unemployed & 68 & 13 & 49 \\
Low-wage & $(10.00 \%)$ & $(37.69 \%)$ \\
& Low-wage & $(52.31 \%)$ & 34 & 99 \\
& & 5 & $(24.64 \%)$ & $(71.74 \%)$ \\
& High-wage & $63 \%)$ & 53 & 1,526 \\
& & $(3.84 \%)$ & $(3.23 \%)$ & $(92.94 \%)$ \\
\hline \hline
\end{tabular}

Source: Samples from SOEP 1984-2007; own calculation, see text.

Table A2a: Job Status 2000 vs. 2003

\begin{tabular}{|c|c|c|c|c|c|c|}
\hline & & Unemployed & Blue-collar & $\begin{array}{c}2003 \\
\text { White-collar }\end{array}$ & $\begin{array}{l}\text { Public } \\
\text { Sector }\end{array}$ & $\begin{array}{c}\text { Self- } \\
\text { employed }\end{array}$ \\
\hline \multirow{5}{*}{2000} & Unemployed & $\begin{array}{c}127 \\
(66.84 \%)\end{array}$ & $\begin{array}{c}42 \\
(22.11 \%)\end{array}$ & $\begin{array}{c}14 \\
(7.37 \%)\end{array}$ & $\begin{array}{c}2 \\
(1.05 \%)\end{array}$ & $\begin{array}{c}5 \\
(2.63 \%)\end{array}$ \\
\hline & Blue-collar & $\begin{array}{c}112 \\
(9.28 \%)\end{array}$ & $\begin{array}{c}986 \\
(81.69 \%)\end{array}$ & $\begin{array}{c}98 \\
(8.12 \%)\end{array}$ & 0 & $\begin{array}{c}11 \\
(0.91 \%)\end{array}$ \\
\hline & White-collar & $\begin{array}{c}42 \\
(3.86 \%)\end{array}$ & $\begin{array}{c}59 \\
(5.42 \%)\end{array}$ & $\begin{array}{c}960 \\
(88.15 \%)\end{array}$ & $\begin{array}{c}7 \\
(0.64 \%)\end{array}$ & $\begin{array}{l}21 \\
(1.93 \%)\end{array}$ \\
\hline & Public Sector & 0 & $\begin{array}{c}1 \\
(0.38 \%)\end{array}$ & $\begin{array}{c}7 \\
(2.69 \%)\end{array}$ & $\begin{array}{c}252 \\
(96.92 \%)\end{array}$ & 0 \\
\hline & $\begin{array}{l}\text { Self- } \\
\text { employed }\end{array}$ & $\begin{array}{c}4 \\
(2.60 \%)\end{array}$ & $\begin{array}{c}5 \\
(3.25 \%)\end{array}$ & $\begin{array}{c}18 \\
(11.69 \%)\end{array}$ & 0 & $\begin{array}{c}127 \\
(82.47 \%)\end{array}$ \\
\hline
\end{tabular}

Source: Samples from SOEP 1984-2007; own calculation, see text.

Table A2b: Job Status 1996 vs. 1999

\begin{tabular}{|c|c|c|c|c|c|c|}
\hline & & Unemployed & Blue-collar & $\begin{array}{c}1999 \\
\text { White-collar }\end{array}$ & $\begin{array}{l}\text { Public } \\
\text { Sector }\end{array}$ & $\begin{array}{c}\text { Self- } \\
\text { employed }\end{array}$ \\
\hline \multirow{10}{*}{1996} & \multirow{2}{*}{ Unemployed } & 80 & 57 & 25 & 1 & 5 \\
\hline & & (47.62\%) & (33.93\%) & (14.88\%) & $(0.60 \%)$ & (2.98\%) \\
\hline & \multirow{2}{*}{ Blue-collar } & 82 & 813 & 47 & 3 & 9 \\
\hline & & (8.60\%) & (85.22\%) & $(4.93 \%)$ & $(0.31 \%)$ & (0.94\%) \\
\hline & \multirow{2}{*}{ White-collar } & 16 & 39 & 534 & 2 & 19 \\
\hline & & $(2.62 \%)$ & $(6.39 \%)$ & (87.54\%) & (0.33\%) & (3.11\%) \\
\hline & \multirow{2}{*}{ Public Sector } & 1 & 0 & 1 & 156 & 1 \\
\hline & & $(0.63 \%)$ & & (0.63\%) & (98.11\%) & $(0.63 \%)$ \\
\hline & Self- & 1 & 8 & 14 & 0 & 65 \\
\hline & employed & $(1.14 \%)$ & $(9.09 \%)$ & (15.91\%) & & (73.86\%) \\
\hline
\end{tabular}

Source: Samples from SOEP 1984-2007; own calculation, see text. 
Table A2c: Job Status 1992 vs. 1995

\begin{tabular}{|c|c|c|c|c|c|c|}
\hline & & Unemployed & Blue-collar & $\begin{array}{c}1995 \\
\text { White-collar }\end{array}$ & $\begin{array}{l}\text { Public } \\
\text { Sector }\end{array}$ & $\begin{array}{c}\text { Self- } \\
\text { employed }\end{array}$ \\
\hline \multirow{5}{*}{1992} & Unemployed & $\begin{array}{c}66 \\
(70.97 \%)\end{array}$ & $\begin{array}{c}22 \\
(23.66 \%)\end{array}$ & $\begin{array}{c}3 \\
(3.23 \%)\end{array}$ & $\begin{array}{c}1 \\
(1.08 \%)\end{array}$ & $\begin{array}{c}1 \\
(1.08 \%)\end{array}$ \\
\hline & Blue-collar & $\begin{array}{c}92 \\
(9.78 \%)\end{array}$ & $\begin{array}{c}777 \\
(82.57 \%)\end{array}$ & $\begin{array}{c}58 \\
(6.16 \%)\end{array}$ & $\begin{array}{c}2 \\
(0.21 \%)\end{array}$ & $\begin{array}{l}12 \\
(1.28 \%)\end{array}$ \\
\hline & White-collar & $\begin{array}{c}26 \\
(4.59 \%)\end{array}$ & $\begin{array}{c}42 \\
(7.42 \%)\end{array}$ & $\begin{array}{c}479 \\
(84.63 \%)\end{array}$ & $\begin{array}{c}5 \\
(0.88 \%)\end{array}$ & $\begin{array}{c}14 \\
(2.47 \%)\end{array}$ \\
\hline & Public Sector & $\begin{array}{c}1 \\
(0.59 \%)\end{array}$ & $\begin{array}{c}2 \\
(1.18 \%)\end{array}$ & $\begin{array}{c}5 \\
(2.96 \%)\end{array}$ & $\begin{array}{c}160 \\
(94.67 \%)\end{array}$ & $\begin{array}{c}1 \\
(0.59 \%)\end{array}$ \\
\hline & $\begin{array}{l}\text { Self- } \\
\text { employed }\end{array}$ & $\begin{array}{c}1 \\
(1.85 \%)\end{array}$ & $\begin{array}{c}7 \\
(12.96 \%)\end{array}$ & $\begin{array}{c}7 \\
(12.96 \%)\end{array}$ & 0 & $\begin{array}{c}39 \\
(72.22 \%)\end{array}$ \\
\hline
\end{tabular}

Source: Samples from SOEP 1984-2007; own calculation, see text.

Table A2d: Job Status 1988 vs. 1991

\begin{tabular}{|c|c|c|c|c|c|c|}
\hline & & Unemployed & Blue-collar & $\begin{array}{c}1991 \\
\text { White-collar }\end{array}$ & $\begin{array}{l}\text { Public } \\
\text { Sector }\end{array}$ & $\begin{array}{c}\text { Self- } \\
\text { employed }\end{array}$ \\
\hline \multirow{5}{*}{1988} & Unemployed & $\begin{array}{c}67 \\
(49.63 \%)\end{array}$ & $\begin{array}{c}54 \\
(40.00 \%)\end{array}$ & $\begin{array}{c}12 \\
(8.89 \%)\end{array}$ & $\begin{array}{c}1 \\
(0.74 \%)\end{array}$ & $\begin{array}{c}1 \\
(0.74 \%)\end{array}$ \\
\hline & Blue-collar & $\begin{array}{c}41 \\
\text { (3.75\%) }\end{array}$ & $\begin{array}{c}987 \\
(90.30 \%)\end{array}$ & $\begin{array}{c}57 \\
(5.22 \%)\end{array}$ & $\begin{array}{c}2 \\
(0.18 \%)\end{array}$ & $\begin{array}{c}6 \\
(0.55 \%)\end{array}$ \\
\hline & White-collar & $\begin{array}{c}12 \\
(2.52 \%)\end{array}$ & $\begin{array}{c}25 \\
(5.24 \%)\end{array}$ & $\begin{array}{c}426 \\
(89.31 \%)\end{array}$ & $\begin{array}{c}6 \\
(1.26 \%)\end{array}$ & $\begin{array}{c}8 \\
(1.68 \%)\end{array}$ \\
\hline & Public Sector & 0 & 0 & $\begin{array}{c}5 \\
(2.40 \%)\end{array}$ & $\begin{array}{c}203 \\
(97.60 \%)\end{array}$ & 0 \\
\hline & $\begin{array}{l}\text { Self- } \\
\text { employed }\end{array}$ & $\begin{array}{c}1 \\
(2.22 \%)\end{array}$ & $\begin{array}{c}1 \\
(2.22 \%)\end{array}$ & $\begin{array}{c}9 \\
(20.00 \%) \\
\end{array}$ & 0 & $\begin{array}{c}34 \\
(75.56 \%) \\
\end{array}$ \\
\hline
\end{tabular}

Source: Samples from SOEP 1984-2007; own calculation, see text.

Table A2e: Job Status 1984 vs. 1987

\begin{tabular}{|c|c|c|c|c|c|c|}
\hline & & & & 1987 & & \\
\hline & & Unemployed & Blue-collar & White-collar & $\begin{array}{l}\text { Public } \\
\text { Sector }\end{array}$ & $\begin{array}{c}\text { Self- } \\
\text { employed }\end{array}$ \\
\hline & Tno & 68 & 45 & 16 & 0 & 1 \\
\hline & Unemployed & (52.31\%) & (34.62\%) & (12.31\%) & & $(0.77 \%)$ \\
\hline & & 55 & 926 & 47 & 1 & 7 \\
\hline & Blue-collar & (5.31\%) & (89.38\%) & (4.54\%) & $(0.10 \%)$ & (0.68\%) \\
\hline & & 11 & 35 & 427 & 4 & 5 \\
\hline 1984 & White-collar & (2.28\%) & (7.26\%) & (88.59\%) & (0.83\%) & (1.04\%) \\
\hline & Public Sector & 0 & 3 & 2 & 202 & 0 \\
\hline & Pubilc sector & & (1.45\%) & (0.97\%) & (97.58\%) & \\
\hline & Self- & 2 & 5 & 4 & 0 & 44 \\
\hline & employed & (3.64\%) & $(9.09 \%)$ & (7.27\%) & & (80.00\%) \\
\hline
\end{tabular}

Source: Samples from SOEP 1984-2007; own calculation, see text. 
Figure A3a: Earnings Mobility Between 1984 and 1987

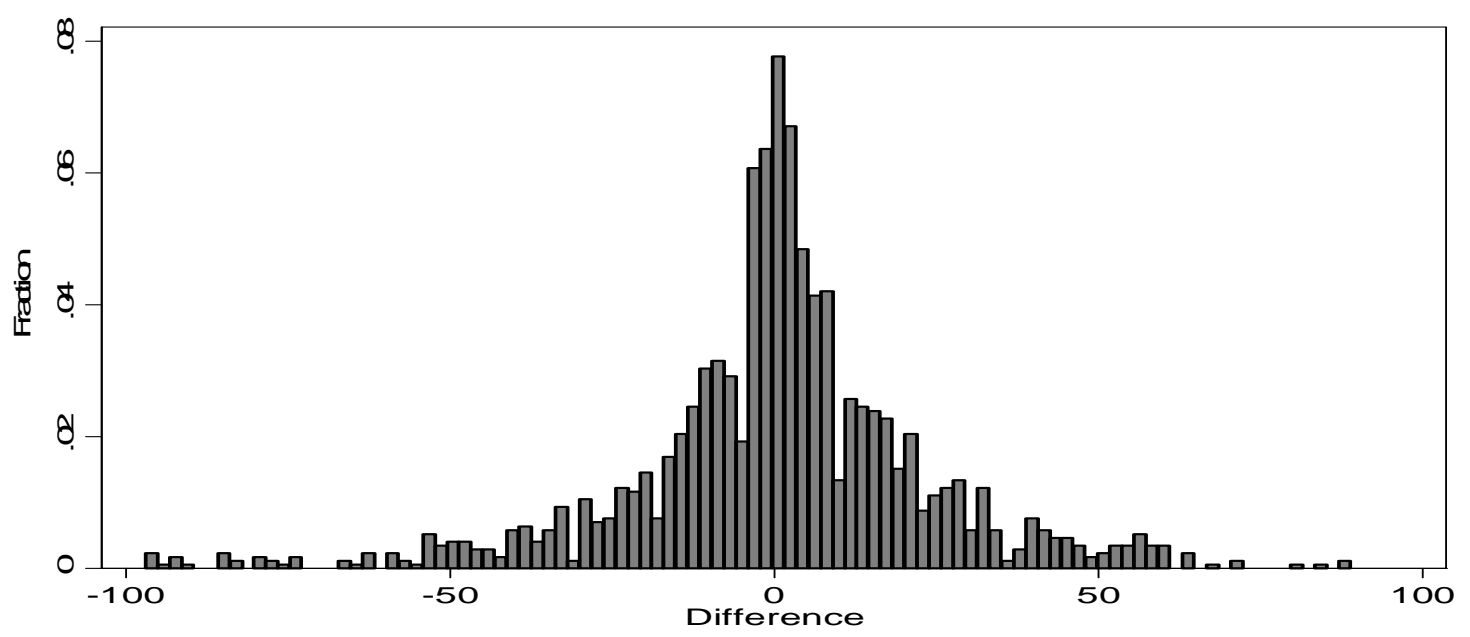

Source: Samples from SOEP 1984-2007; own calculation, see text.

Figure A3b: Earnings Mobility Between 1988 and 1991

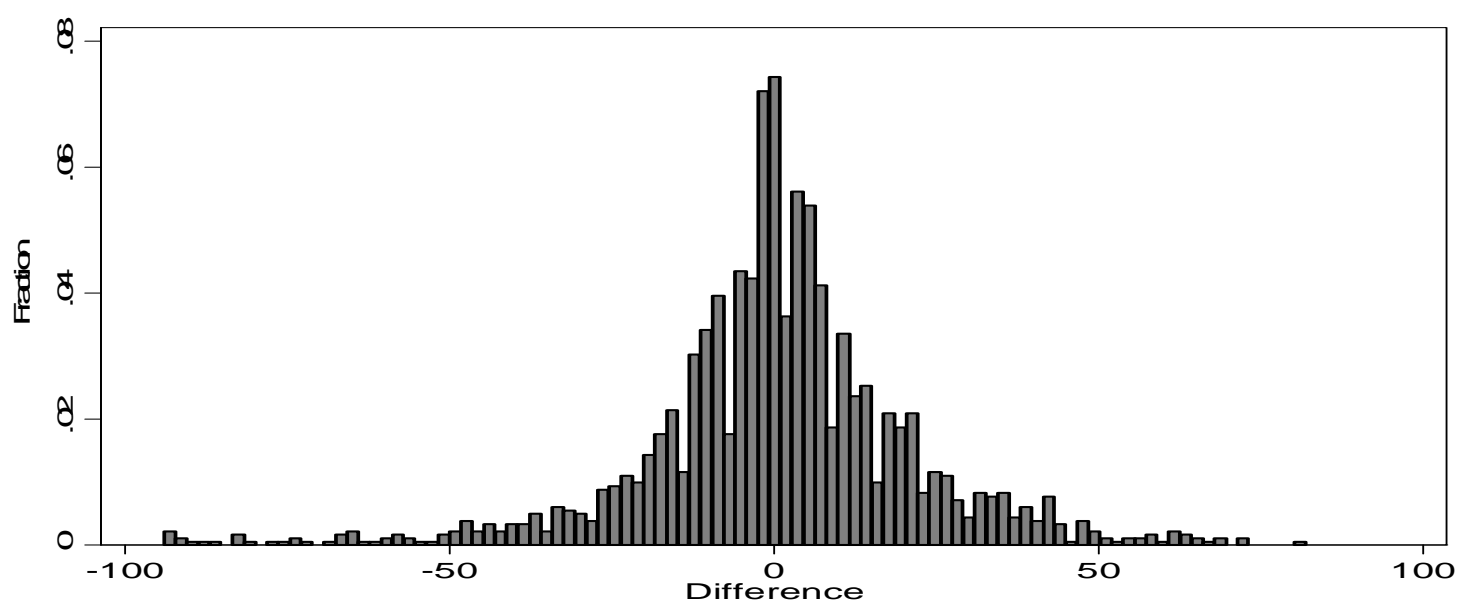

Source: Samples from SOEP 1984-2007; own calculation, see text.

Figure A3c: Earnings Mobility Between 1992 and 1995

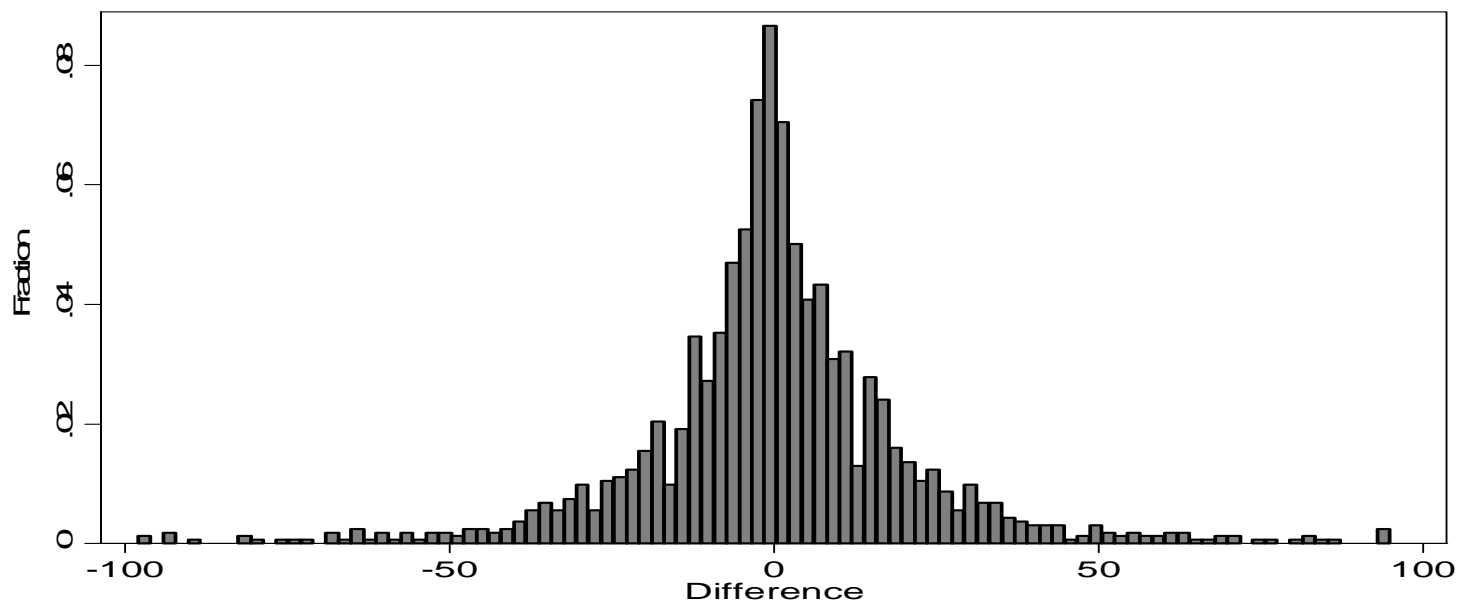

Source: Samples from SOEP 1984-2007; own calculation, see text. 
Figure A3d: Earnings Mobility Between 1996 and 1999

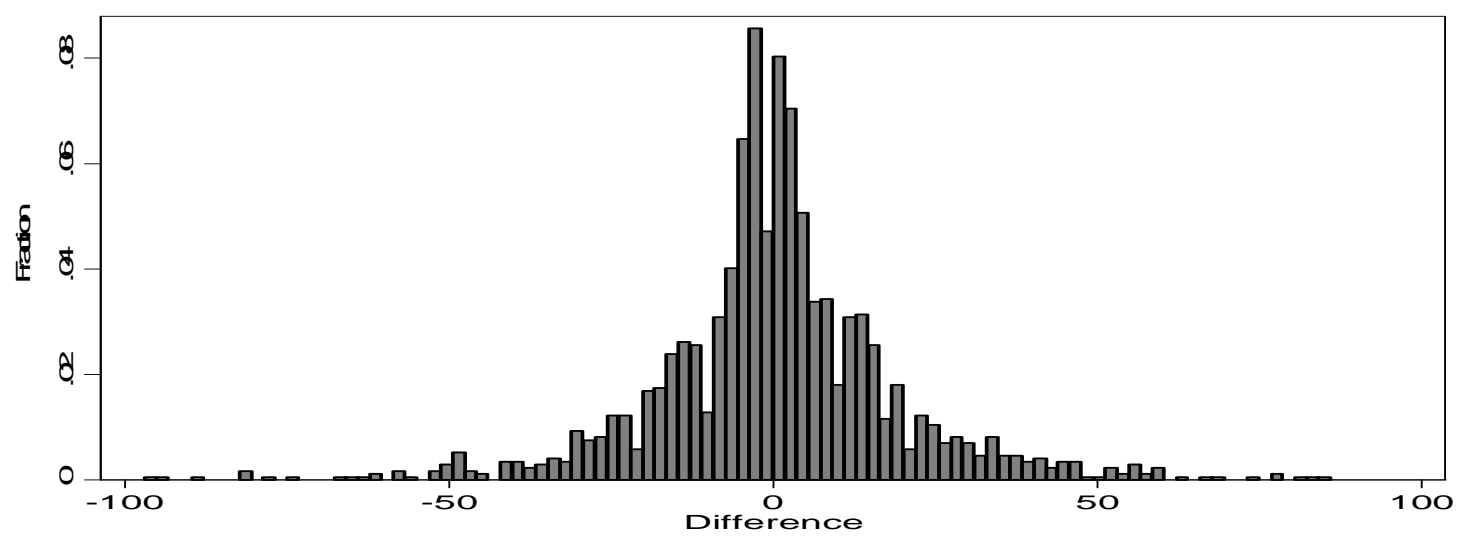

Source: Samples from SOEP 1984-2007; own calculation, see text.

Figure A3e: Earnings Mobility Between 2000 and 2003

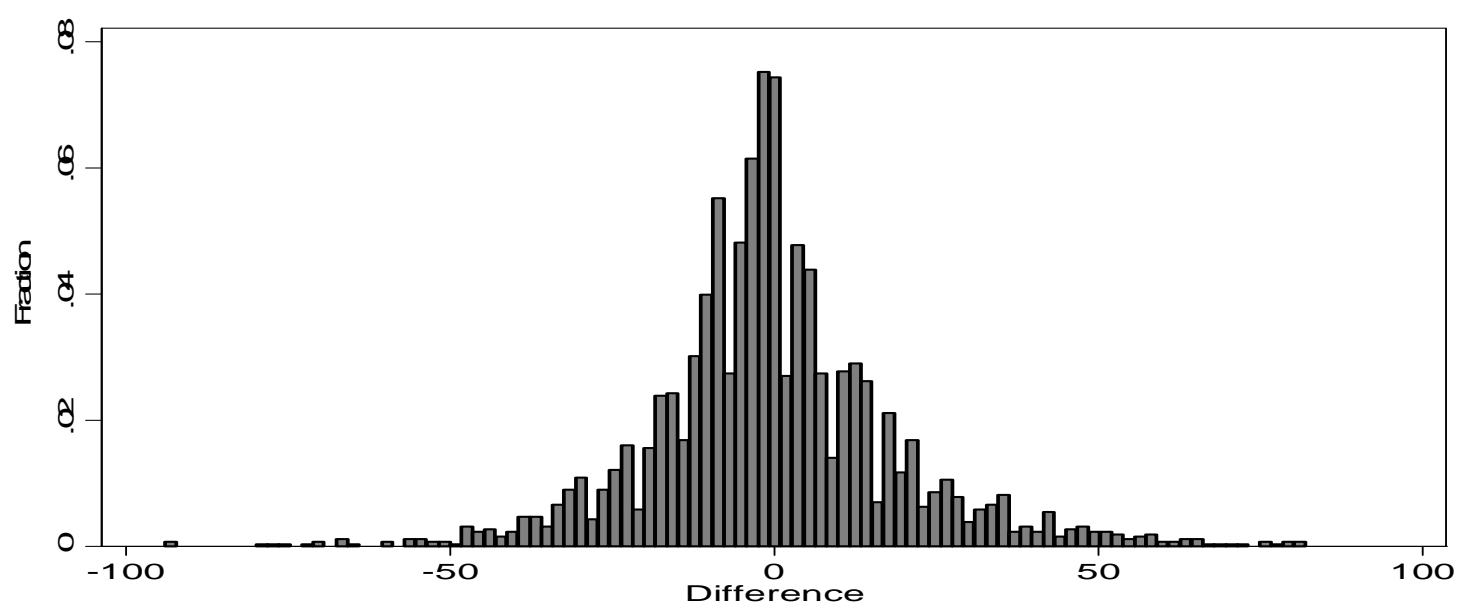

Source: Samples from SOEP 1984-2007; own calculation, see text. 
Table A4: Change in Relative Income Position

\begin{tabular}{|c|c|c|c|}
\hline & 1988/1991 & 1996/1999 & $2000 / 2003$ \\
\hline Wage Percentile (Start Year) (base: 50th) & $\mathrm{nr}$ & $\mathrm{nr}$ & $\mathrm{nr}$ \\
\hline \multicolumn{4}{|l|}{ Age (Base: $50-$ ) } \\
\hline-29 & 2.31 & 1.11 & -0.29 \\
\hline 30-39 & 1.12 & 1.94 & 0.28 \\
\hline $40-49$ & 0.84 & -0.00 & -0.34 \\
\hline Academic Education & $4.76 * *$ & $3.08 *$ & $2.78 * *$ \\
\hline \multicolumn{4}{|l|}{ Industry (Base: Administration, Education) } \\
\hline High-tech Industry & $5.27 * *$ & $4.24 * *$ & $4.25 * *$ \\
\hline Traffic, Distribution & 1.49 & -0.68 & -0.62 \\
\hline Financial Services & 3.90 & $6.82 * * *$ & $3.89 * *$ \\
\hline Others & $\mathrm{nr}$ & $\mathrm{nr}$ & $\mathrm{nr}$ \\
\hline \multicolumn{4}{|l|}{ Occupation (Base: Professionals) } \\
\hline Clerks & $-6.94 * * *$ & $-5.51 * *$ & $-4.30 * *$ \\
\hline Service Workers & $-8.03 * * *$ & $-15.69 * * *$ & $-9.97 * * *$ \\
\hline Craft Workers & -3.12 & $-7.11 * * *$ & $-9.14 * * *$ \\
\hline Plant and Machine Operators & $-8.28 * * *$ & $-6.07 * *$ & $-8.77 * * *$ \\
\hline Elementary & $-8.65 * * *$ & $-8.98 * * *$ & $-8.99 * * *$ \\
\hline Others & $\mathrm{nr}$ & $\mathrm{nr}$ & $\mathrm{nr}$ \\
\hline \multicolumn{4}{|l|}{ Job Change in } \\
\hline Year 1 & -1.33 & -1.92 & $-3.16 * *$ \\
\hline Year 2 & 2.33 & -1.26 & $3.94 * * *$ \\
\hline Year 3 & -0.22 & $-3.07 *$ & 2.02 \\
\hline Year 4 & 1.09 & 2.82 & -1.39 \\
\hline \multicolumn{4}{|l|}{ Firm Size (Base -19) } \\
\hline 20-199 & $3.58 * *$ & $4.86 * * *$ & 0.04 \\
\hline 200-1999 & $5.52 * * *$ & $6.33 * * *$ & 1.43 \\
\hline $2000-$ & $7.09 * * *$ & $7.55 * * *$ & $3.77 * * *$ \\
\hline \multicolumn{4}{|l|}{ Unemployed in } \\
\hline Year 2 & $-26.81 * * *$ & -3.88 & 0.85 \\
\hline Year 3 & $13.32 * *$ & $-16.10 * *$ & $-9.20 * *$ \\
\hline \multicolumn{4}{|l|}{ Job Status (Base: Blue-collar) } \\
\hline White-collar & $5.07 * * *$ & $3.76 * *$ & 1.13 \\
\hline Public sector & 2.63 & $5.46 * *$ & -1.24 \\
\hline Self-employed & $9.14 * *$ & 0.61 & $3.88 *$ \\
\hline Migrational Background & -1.40 & $-1.90 *$ & 0.64 \\
\hline Constant & -14.45 & -8.19 & 1.93 \\
\hline $\mathbf{N}$ & 1,485 & 1,561 & 2,339 \\
\hline Adj. R-squared & 0.32 & 0.20 & 0.19 \\
\hline
\end{tabular}

Source: Samples from SOEP 1984-2007; nr - results not reported in the table; Others - all other groups are separately accounted for in the estimation; *** - significant at the $1 \%$ level, ** - at the $5 \%$ level, * - at the $10 \%$ level; own calculation, see text. 
Figure A5a: Log. Wage Volatility 1984-1987

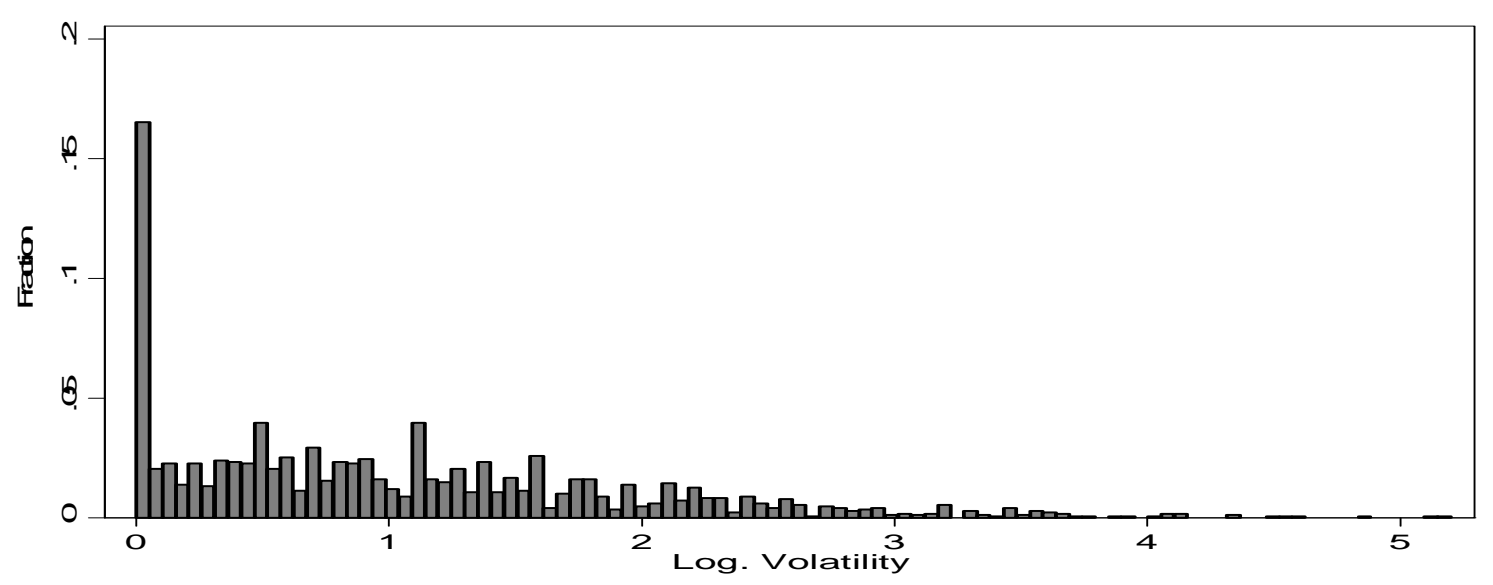

Source: Samples from SOEP 1984-2007; own calculation, see text.

Figure A5b: Log. Wage Volatility 1988-1991

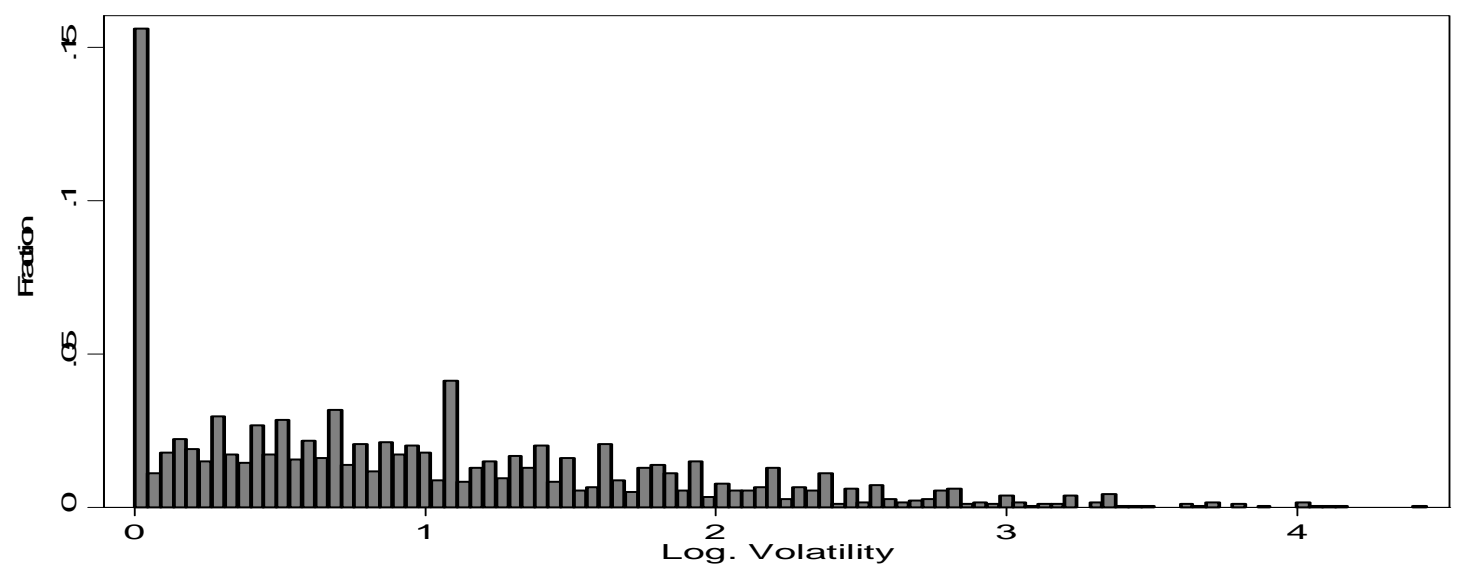

Source: Samples from SOEP 1984-2007; own calculation, see text.

Figure A5c: Log. Wage Volatility 1992-1995

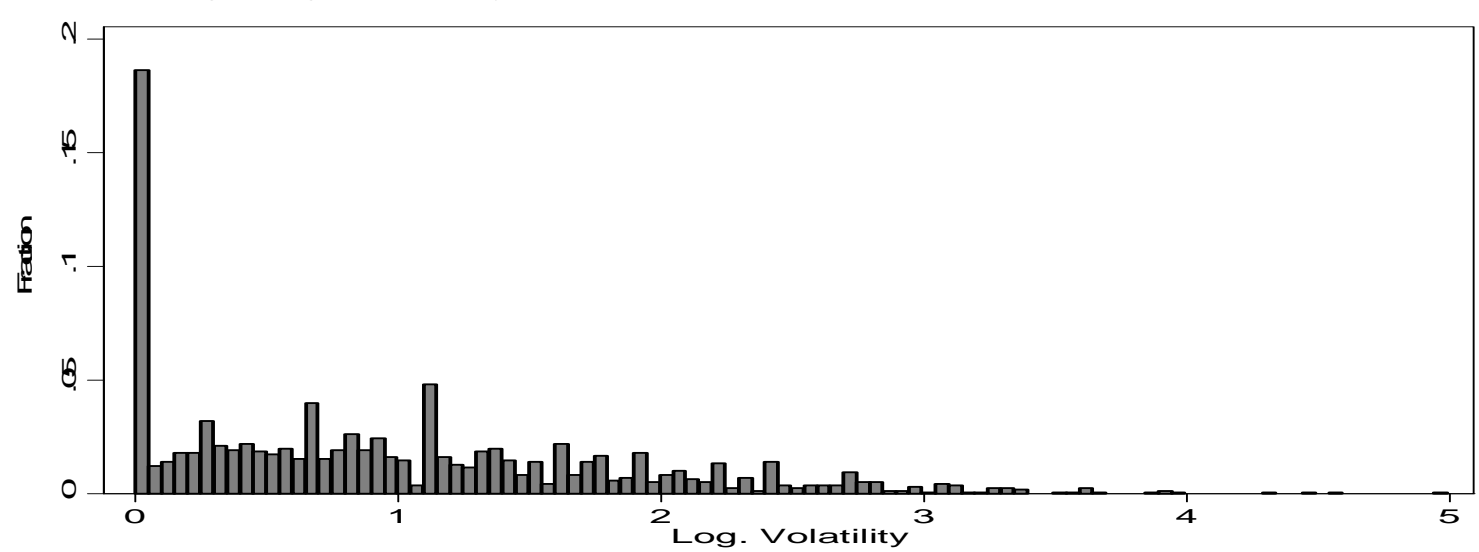

Source: Samples from SOEP 1984-2007; own calculation, see text. 
Figure A5d: Log. Wage Volatility 1996-1999

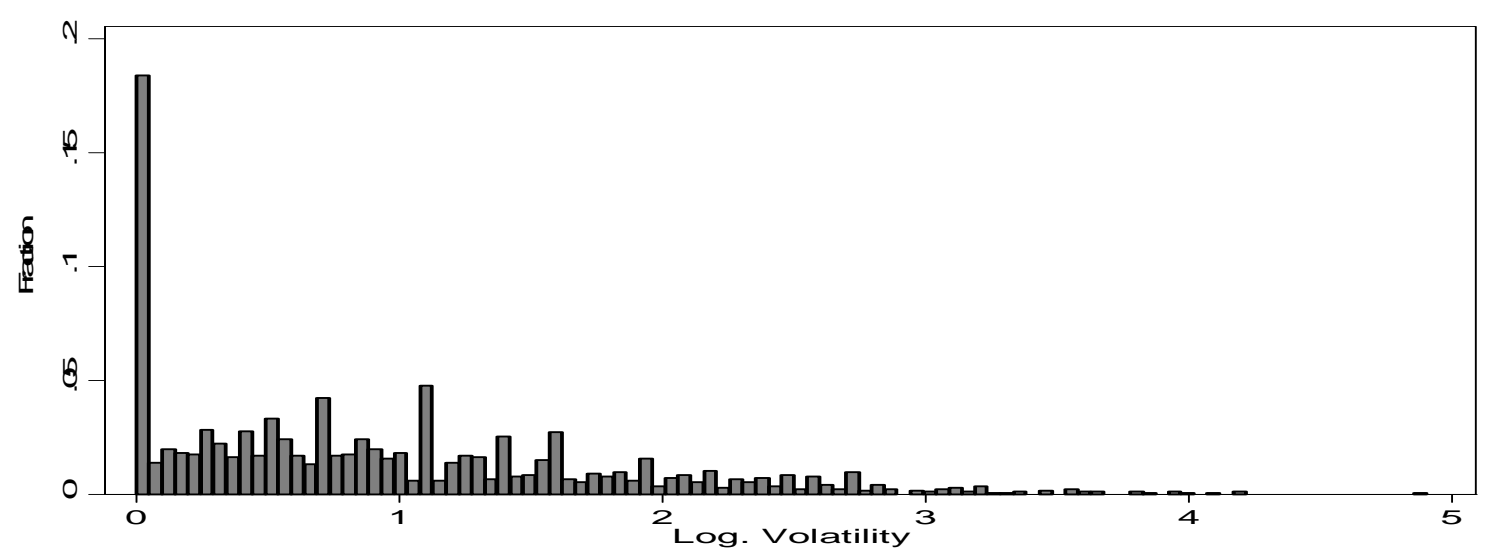

Source: Samples from SOEP 1984-2007; own calculation, see text.

Figure A5e: Log. Wage Volatility 2000-2003

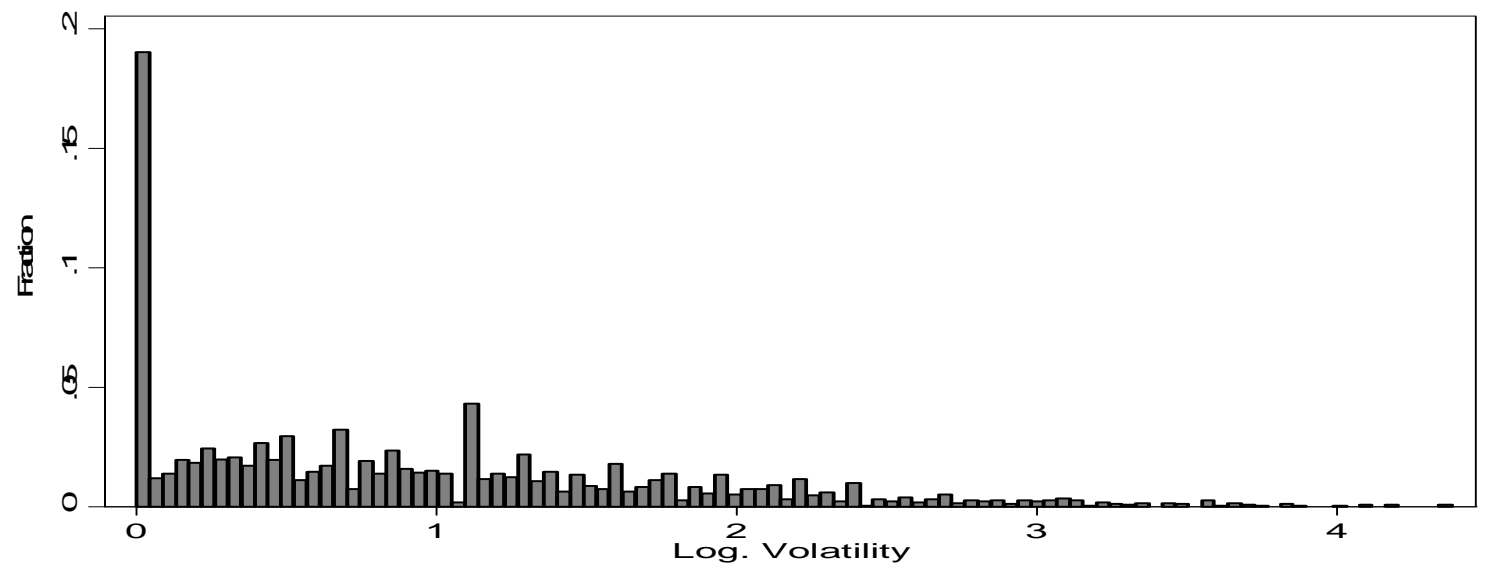

Source: Samples from SOEP 1984-2007; own calculation, see text.

\subsection{Wage Mobility and Volatility for Females}

In contrast to the study of Raferzeder and Winter-Ebmer (2007), the data at hand also allows to analyse females and to compare the results with those for males. I adopt the same definitions and procedures described in the former sections. Employment rates for females are far below the levels for males. Nevertheless, they increased sharply from 45\% in 1984/1987 to $66 \%$ in $2004 / 2007$, while employment rates for males decreased slightly from $93 \%$ to $89 \%$ during this time. In absolute terms, there are more females in the data, but with regard to the lower employment rates, particularly in the 1980s, there are fewer observations of wages, resulting in higher confidence intervals and thus in several insignificant coefficients for the change in relative income positions in Table A7. The main result in the sense of this study is that wage mobility, measured by the standard deviation of the rank wage differences, also decreases for females by about 4 points, compared to about 5.5 points for males. While in the 
first four time periods mobility is higher for males, in 2000/2003 and 2004/2007 mobility is higher for females.

Table A6: Mobility in Several Time Periods, Females

\begin{tabular}{lcccc}
\hline \hline Time Period & $\begin{array}{c}\text { Yearly } \\
\text { Observations } \\
\text { (Balanced Panel) }\end{array}$ & $\begin{array}{c}\text { Employment } \\
\text { Rate }\end{array}$ & $\begin{array}{c}\text { Real Gross } \\
\text { Hourly Wage, } \\
\text { Median }\end{array}$ & $\begin{array}{c}\text { Standard Deviation of } \\
\text { Rank Differences, } \\
\text { Mobility }\end{array}$ \\
\hline $\mathbf{2 0 0 4 - 2 0 0 7}$ & 3,141 & 0.66 & 12.44 & 18.52 \\
$\mathbf{2 0 0 0 - 2 0 0 3}$ & 3,375 & 0.63 & 12.40 & 19.60 \\
$\mathbf{1 9 9 6 - 1 9 9 9}$ & 2,165 & 0.60 & 12.12 & 18.53 \\
$\mathbf{1 9 9 2 - 1 9 9 5}$ & 2,078 & 0.58 & 11.61 & 20.12 \\
$\mathbf{1 9 8 8 - 1 9 9 1}$ & 2,101 & 0.54 & 10.85 & 20.50 \\
$\mathbf{1 9 8 4 - 1 9 8 7}$ & 2,234 & 0.45 & 9.98 & 22.41 \\
\hline \hline
\end{tabular}

Source: Samples from SOEP 1984-2007; weighted data; own calculation, see text.

I iterate the regression of characteristics to the amount of wage mobility as done in section 5 for males. The age effect is higher for females. Compared to the reference group of persons older than 50, younger females face higher upward moves than males. Academic education also leads to upward mobility for females, highest in the period 1992/1995 with about 10 ranks and then decreasing to about 4 while it is not significant in 1996/1999 and the two earliest periods. Industry effects and occupation effects have the same signs as for males but are more pronounced. Particularly females doing elementary jobs face a 14 ranks (compared to 8 ranks for males) higher downward movement compared to females with a professional occupation in 2004/2007. Females also face higher chances of moving upwards in larger firms, the effect being highest in the second largest group, with a firm size between 200 and 1,999 employees, while for males, the effects are highest in firms with more than 2,000 employees. At least in 2004/2007 not being a blue-collar worker has a higher effect for females compared to males.

Overall, wage volatility for females lies at the same level as for males in most years, and in some time periods (1988/1991, 1992/1995 and 1996/1999) it is slightly higher. It also decreases over time. Volatility is higher for low-wage earners in all time periods and even higher compared to males in 1984/1987 and 1988/1991. The wage volatility for females moving upwards is higher compared to males in all periods, with the exception of 1988/1991. 
Table A7: Change in Relative Income Position, Females

\begin{tabular}{|c|c|c|c|c|}
\hline & $2004 / 2007$ & $\begin{array}{c}\text { 2004/2007 } \\
\text { PADAE }\end{array}$ & 1992/ 1995 & 1984/1987 \\
\hline Wage Percentile (Starting Year) (Base: 50th) & $\mathrm{nr}$ & $\mathrm{nr}$ & $\mathrm{nr}$ & $\mathrm{nr}$ \\
\hline \multicolumn{5}{|l|}{ Age (Base: $50-)$} \\
\hline-29 & $2.74 *$ & $3.57 * *$ & 0.99 & 1.68 \\
\hline $30-39$ & $3.75 * * *$ & 2.02 & $3.37 *$ & 3.80 \\
\hline $40-49$ & $2.32 * *$ & 1.75 & $4.44 * *$ & 2.08 \\
\hline Academic Education & $4.27 * * *$ & $4.23 * * *$ & $9.74 * * *$ & 4.52 \\
\hline \multicolumn{5}{|l|}{ Industry (Base: Administration, Education) } \\
\hline High-tech Industry & $6.73 * * *$ & $5.51 * * *$ & 2.07 & $6.07 *$ \\
\hline Traffic, Distribution & $5.63 * * *$ & $5.78 * * *$ & $10.60 * * *$ & -0.69 \\
\hline Financial Services & $6.39 * * *$ & $4.78 * *$ & 1.58 & 4.33 \\
\hline Others & $\mathrm{nr}$ & $\mathrm{nr}$ & $\mathrm{nr}$ & $\mathrm{nr}$ \\
\hline \multicolumn{5}{|l|}{ Occupation (Base: Professionals) } \\
\hline Clerks & $-6.33 * * *$ & $-7.65 * * *$ & $-8.02 * *$ & $-9.33 *$ \\
\hline Service Workers & $-10.27 * * *$ & $-11.21 * * *$ & $-12.69 * * *$ & $-18.01 * * *$ \\
\hline Craft Workers & $-9.95 * * *$ & $-7.43 * *$ & $-9.21 *$ & $-13.86 * *$ \\
\hline Plant and Machine Operators & $-9.89 * * *$ & $-10.16 * * *$ & $-12.07 * *$ & $-20.00 * * *$ \\
\hline Elementary & $-14.13 * * *$ & $-15.63 * * *$ & $-15.11 * * *$ & $-23.01 * * *$ \\
\hline Others & $\mathrm{nr}$ & $\mathrm{nr}$ & $\mathrm{nr}$ & $\mathrm{nr}$ \\
\hline \multicolumn{5}{|l|}{ Job Change in } \\
\hline Year 1 & -1.94 & -1.94 & -2.02 & - \\
\hline Year 2 & 1.33 & 1.29 & $5.12 * *$ & 4.31 \\
\hline Year 3 & $-2.96 *$ & -1.06 & -0.91 & -1.54 \\
\hline Year 4 & $-3.36 * *$ & $-3.48 *$ & -1.35 & - \\
\hline \multicolumn{5}{|l|}{ Firm Size (Base -19) } \\
\hline 20-199 & -0.90 & 0.47 & $6.27 * * *$ & $3.50 *$ \\
\hline 200-1999 & $3.37 * * *$ & $4.23 * * *$ & $9.11 * * *$ & $6.81 * * *$ \\
\hline $2000-$ & 1.57 & $2.58 * *$ & $6.75 * * *$ & $6.47 * * *$ \\
\hline \multicolumn{5}{|l|}{ Unemployed in } \\
\hline Year 2 & $-12.41 * * *$ & - & $12.47 * *$ & 3.01 \\
\hline Year 3 & -0.80 & - & $-13.55 * * *$ & $-7.87 *$ \\
\hline \multicolumn{5}{|l|}{ Job Status (Base: Blue-collar) } \\
\hline White-collar & $4.14 * * *$ & $5.27 * * *$ & $4.41 *$ & 3.28 \\
\hline Public sector & $6.88 * * *$ & $5.00 * *$ & 2.28 & -0.85 \\
\hline Self-employed & $9.03 * * *$ & - & $19.30 * * *$ & -12.14 \\
\hline Migration Background & -1.81 & -1.62 & $-3.06 *$ & -1.24 \\
\hline Constant & -2.82 & -1.77 & -1.40 & -10.80 \\
\hline $\mathbf{N}$ & 1,823 & 1,520 & 875 & 718 \\
\hline Adj. R-squared & 0.26 & 0.25 & 0.33 & 0.36 \\
\hline
\end{tabular}

Source: Samples from SOEP 1984-2007; nr - results not reported in the table; PADAE - Prime age dependent (in starting year) and always employed; Others - all other groups are separately accounted for in the estimation; *** - significant at the $1 \%$ level, ** - at the $5 \%$ level, * - at the $10 \%$ level; own calculation, see text. 
Table A7b: Change in Relative Income Position, Females

\begin{tabular}{|c|c|c|c|}
\hline & 1988/1991 & 1996/1999 & $2000 / 2003$ \\
\hline Wage Percentile (Start Year) (Base: 50th) & $\mathrm{nr}$ & $\mathrm{nr}$ & $\mathrm{nr}$ \\
\hline \multicolumn{4}{|l|}{ Age (Base: $50-$ ) } \\
\hline-29 & 2.49 & $3.91 * *$ & $4.16 * * *$ \\
\hline 30-39 & 2.69 & 2.74 & $4.18 * * *$ \\
\hline $40-49$ & 1.65 & 2.21 & $3.06 * *$ \\
\hline Academic Education & 1.53 & 0.94 & $4.65 * * *$ \\
\hline \multicolumn{4}{|l|}{ Industry (Base: Administration, Education) } \\
\hline High-tech Industry & -1.17 & 0.92 & 3.86 \\
\hline Traffic, Distribution & -1.99 & 3.03 & $4.61 *$ \\
\hline Financial Services & 3.52 & 0.18 & $4.07 *$ \\
\hline Others & $\mathrm{nr}$ & $\mathrm{nr}$ & $\mathrm{nr}$ \\
\hline \multicolumn{4}{|l|}{ Occupation (Base: Professionals) } \\
\hline Clerks & $-11.64 * *$ & $-5.66 * *$ & $-7.17 * * *$ \\
\hline Service Workers & $-12.36 * *$ & $-8.76 * *$ & $-10.27 * * *$ \\
\hline Craft Workers & $-16.37 * * *$ & $-7.67 *$ & $-12.01 * * *$ \\
\hline Plant and Machine Operators & $-18.41 * * *$ & $-9.31 * *$ & $-12.75 * * *$ \\
\hline Elementary & $-20.61 * * *$ & $-9.78 * * *$ & $-12.23 * * *$ \\
\hline Others & $\mathrm{nr}$ & $\mathrm{nr}$ & $\mathrm{nr}$ \\
\hline \multicolumn{4}{|l|}{ Job Change in } \\
\hline Year 1 & -1.17 & 1.40 & $-2.81 *$ \\
\hline Year 2 & 0.31 & $5.59 * *$ & $2.88 *$ \\
\hline Year 3 & 3.27 & $-10.00 * * *$ & 1.84 \\
\hline Year 4 & 3.46 & -2.47 & 1.87 \\
\hline \multicolumn{4}{|l|}{ Firm Size (Base -19) } \\
\hline 20-199 & $6.43 * * *$ & 1.62 & $3.36 * * *$ \\
\hline 200-1999 & $9.12 * * *$ & $3.58 * *$ & $5.52 * * *$ \\
\hline $2000-$ & $7.96 * * *$ & $5.63 * * *$ & $5.81 * * *$ \\
\hline \multicolumn{4}{|l|}{ Unemployed in } \\
\hline Year 2 & $-12.53 *$ & -0.51 & $-12.99 * * *$ \\
\hline Year 3 & 0.76 & $-8.52 *$ & $-6.50 * *$ \\
\hline \multicolumn{4}{|l|}{ Job Status (Base: Blue-collar) } \\
\hline White-collar & $5.58 *$ & $3.98 * *$ & $5.48 * * *$ \\
\hline Public sector & 5.60 & 3.37 & $5.58 * *$ \\
\hline Self-employed & 4.72 & 3.25 & 4.21 \\
\hline Migrational Background & -2.32 & 0.92 & 0.84 \\
\hline Constant & 7.17 & -5.67 & 2.07 \\
\hline $\mathbf{N}$ & 581 & 947 & 1,626 \\
\hline Adj. R-squared & 0.35 & 0.22 & 0.25 \\
\hline
\end{tabular}

Source: Samples from SOEP 1984-2007; nr - results not reported in the table; Others - all other groups are separately accounted for in the estimation; *** - significant at the $1 \%$ level, ** - at the $5 \%$ level, * - at the $10 \%$ level; own calculation, see text.

Table A8: Volatility in 4-year Periods, Females

\begin{tabular}{lcccccc} 
& $\mathbf{8 4 / 8 7}$ & $\mathbf{8 8 / 9 1}$ & $\mathbf{9 2 / 9 5}$ & $\mathbf{9 6 / 9 9}$ & $\mathbf{0 0 / 0 3}$ & $\mathbf{0 4 / 0 7}$ \\
\hline Overall & 4.85 & 4.51 & 4.89 & 4.85 & 4.18 & 4.24 \\
\hline Low-wage & 5.98 & 4.68 & 5.64 & 4.54 & 4.36 & 4.51 \\
High-wage & 4.25 & 4.42 & 4.53 & 4.97 & 4.07 & 4.10 \\
\hline Moving Upwards & 4.01 & 3.35 & 4.13 & 3.85 & 3.89 & 3.54 \\
Moving Downwards & 4.29 & 3.90 & 3.94 & 4.45 & 3.68 & 4.05 \\
\hline \hline
\end{tabular}

Source: Samples from SOEP 1984-2007; own calculation, see text. 